$25 / 194950$

$\prod_{\triangle E G S G}$

ENERGY MEASUREMENTS

EGG 11265-1018

LABORATORY

UC-702

OPERATED FOR THE U.S.

AUGUST 1994

HISTORICAL WETLANDS MAPPING AND GIS PROCESSING FOR THE SAVANNAH RIVER SITE DATABASE

AIKEN, SOUTH CAROLINA 


\section{DISCLAIMER}

Portions of this document may be illegible in electronic image products. Images are produced from the best available original document. 


\title{
HISTORICAL WETLANDS MAPPING AND GIS PROCESSING FOR THE SAVANNAH RIVER SITE DATABASE
}

\author{
L. M. Christel \\ Project Scientist
}

The DOE Remote Sensing Laboratory Operated for the U.S. Department of Energy by

EG\&G Energy Measurements, inc.

Las Vegas, Nevada

\section{REVIEWED BY}

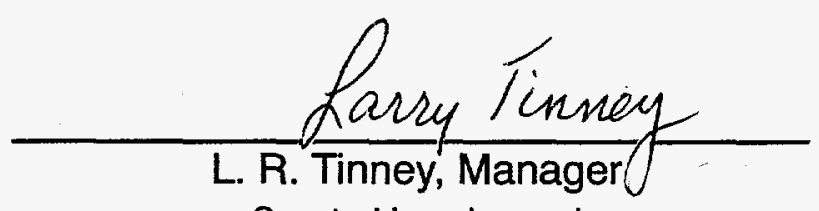

Spectral Imaging and

Geographic Information Systems Section

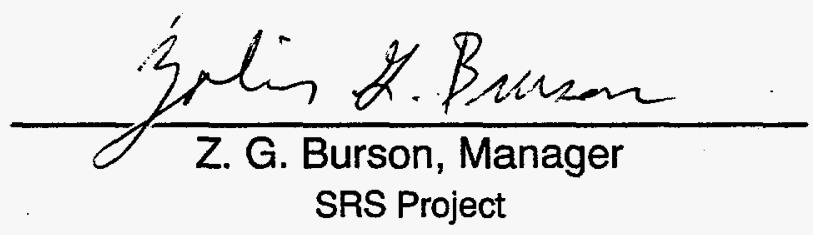

This Document is UNCLASSIFIED

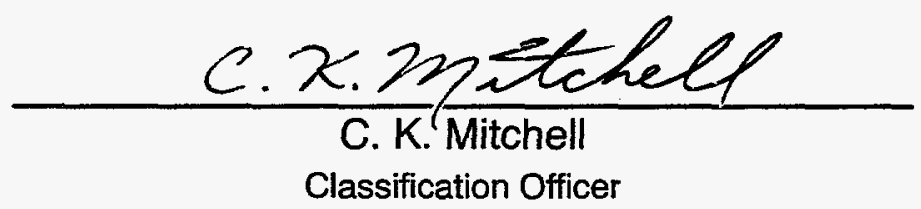

This work was performed by EG\&G/EM under Contract Number DE-AC08-93NV11265 with joint funding provided by the United States Department of Energy and Westinghouse Savannah River Company, operators of the Savannah River Site and Savannah River Technology Center. 


\begin{abstract}
New policies regarding the "no net loss" of wetlands have presented resource managers and GIS analysts with a challenging ecological application. Historical aerial photography provides a temporal record of conditions over time. Access to temporal data sources is beneficial when appraising wetland gain and loss because manmade disturbances can have both short and long term effects on wetland communities. This is particularly true when trying to assess the existing communities for the specific purpose of restoration and reclamation of the ecologic structure and function of the community prior to a disturbance. Remediation efforts can be optimized when definitive documentation exists of the original communities. The Geographic Information System (GIS) is a powerful tool for integrating these data sets and performing spatial and temporal analyses in support of ecological applications.
\end{abstract}

The Savannah River Site (SRS) is owned by the U.S. Department of Energy and operated by Westinghouse Savannah River Company. The land was privately owned prior to the startup of SRS nuclear facilities in 1952. Temporal analysis of multispectral scanner data has shown where wetlands were impacted by reactor operation, such as thermal discharge into creeks and swamps, and where wetlands were removed due to the construction of facilities. The GIS database was used to determine how the distribution and composition of wetland classes have changed over time.

Black and white aerial photography of SRS was acquired prior to any operations on the site. Color infrared aerial photography as recent as 1989 also exists and was used to develop a more current land cover database. Six wetland classes were photointerpreted from the early photographs and included in the GIS. The same six wetland classes were derived from the 1989 land cover data. The historical data layer was then used in spatial analyses to aid in deriving potential viable and cost effective management technique alternatives for remediation of wetlands influenced by past reactor operations. This layer has also provided acreage estimates of wetlands lost. These acreage values can be used to estimate the potential costs of wetland remediation at SRS. This application of temporal analysis using a GIS demonstrates not only the utility of documenting prior conditions before remediation actually commences, but also how to maximize the cost effectiveness of remediation efforts. 


\section{CONTENTS}

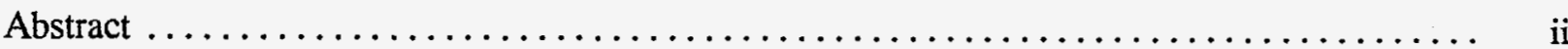

\section{Sections}

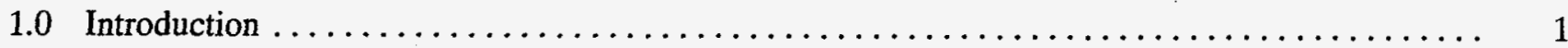

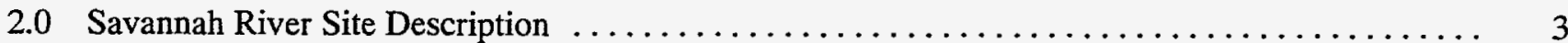

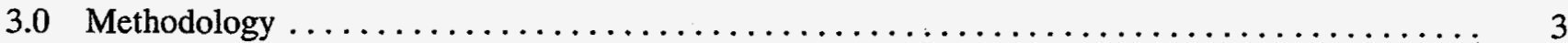

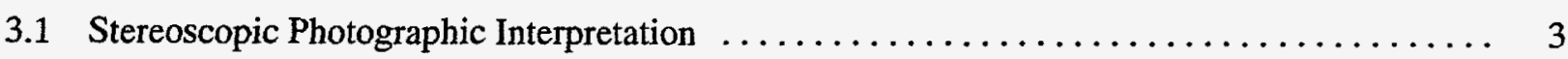

3.2 Geographic Information System Processing $\ldots \ldots \ldots \ldots \ldots \ldots \ldots \ldots \ldots \ldots \ldots \ldots \ldots$

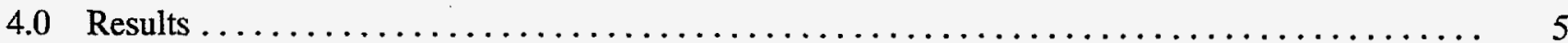

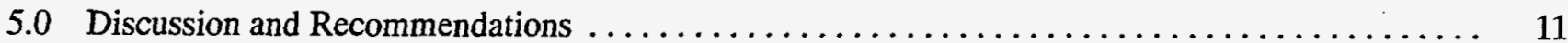

\section{Figures}

1 Flight Line Plan for the Aerial Photography Acquired by the U.S.

Department of Agriculture in 1943 and the U.S. Army Corps of

Engineers in 1951

2 Historical Wetlands Map (SRS-93-113.1) Interpreted from 1943 and

1951 Black and White Historical Photography . . . . . . . . . . . . . . . . . . . .

3 Recent Wetlands Map (SRS-93-142.1) Interpreted from 1989 Color Infrared

Aerial Photography

4 Pen Branch Delta Wetland Class Map (SRS-93-003.0) as Interpreted from

Historical Photography

\section{Tables}

1 Sitewide Estimates for the Overall Net Gain or Loss of Six Wetland Classes Between 1951 and 1989 in Hectares ............................. 5

2 Area Estimates of 1951 Wetland Classes by Quadrangle in Hectares $\ldots \ldots \ldots \ldots \ldots \ldots \ldots$

3 Estimates of Net Gain or Loss of Wetland Class Areas by Quadrangle Between 1951 and 1989 in Hectares . . . . . . . . . . . . . . . . . . . . . . . . . . . . . . . . . 10

4 Minimum and Maximum Areas for Pre- and Post-SRS Wetland Classes in Hectares

\section{Appendices}

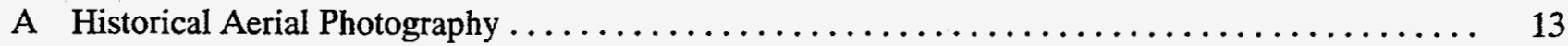

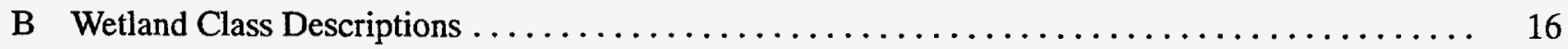

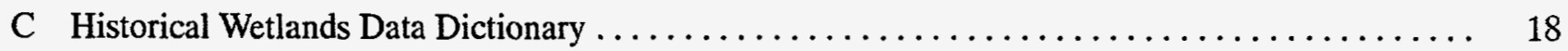

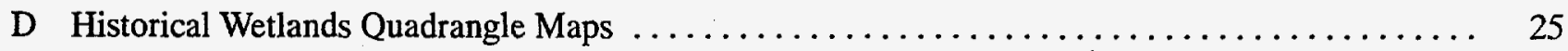

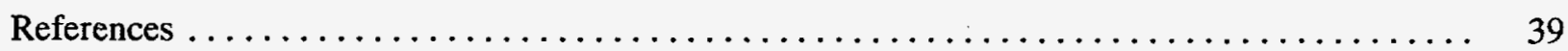




\subsection{INTRODUCTION}

The Savannah River Site (SRS) is owned by the United States Department of Energy and was operated by E.I. du Pont de Nemours and Company, Inc., until 1989 when Westinghouse Savannah River Company took over management of the facility. SRS, comprised of approximately 77,700 hectares, was privately owned prior to the startup of SRS nuclear facilities in 1952 . Roughly $25 \%$ of the land cover is wetland community. Recent Federal policies regarding the "no net loss" of wetlands have presented resource managers at SRS with the ecological challenges of remediation and restoration.

When assessing wetland gain and loss, access to temporal data sources is beneficial because man-made disturbances can have both short and long term effects on diverse wetland communities. This is particularly true when trying to assess existing communities for the specific purpose of restoration and reclamation of the ecologic structure and function of the community prior to a disturbance. Several sets of black and white aerial photography, dated prior to operations at SRS, were acquired by the U.S. Department of Agriculture and U.S. Army Corps of Engineers. Flight lines for the multidate sitewide acquisition are shown in Figure 1. The specific dates of each photograph used to obtain complete sitewide coverage for SRS are listed in Appendix A. These photographs provided the sitewide baseline information to which recent information can be compared.

Wetland data were interpreted from several dates of aerial photography using stereoscopic photographic interpretation techniques. The classification scheme is comprised of six forested and nonforested wetland classes based upon a scheme developed by the U.S. Fish and Wildlife Service (Cowardin et al., 1979). Refer to Appendix $\mathrm{B}$ for the descriptions of these classes.

The information was entered into a digital geographic information system (GIS) to support timely analyses based on spatial and thematic attributes. Initially, the data were used to estimate the area of each wetland class represented historically and for mapping purposes. The availability of an existing current land cover data layer that was developed in a similar manner to the historical data layer facilitated further analyses that included estimating net gain and loss in specific wetland classes since the establishment of the SRS.

The discussions that follow include: 1) a brief description of the site prior to and after operations of the SRS nuclear production facility, 2) the methodology used to incorporate the data into the GIS, and 3) a synopsis of early results derived from the initial analyses. The final section provides discussion regarding possible future applications of the historical data and recommendations based upon this experience. 


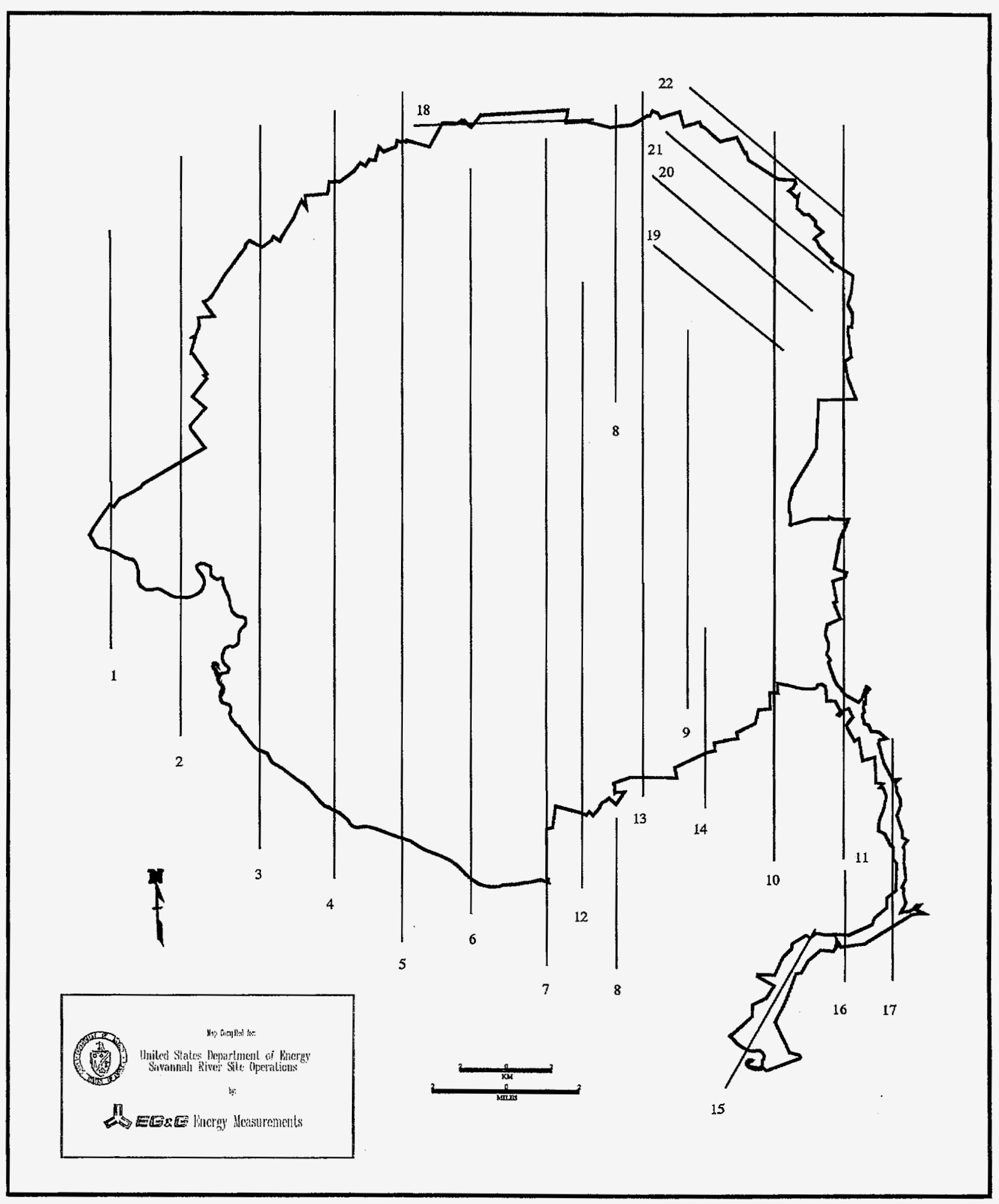

FIGURE 1. FLIGHT LINE PLAN FOR THE AERIAL PHOTOGRAPHY ACQUIRED BY THE U.S. DEPARTMENT OF AGRICULTURE IN 1943 AND THE U.S. ARMY CORPS OF ENGINEERS IN 1951 


\subsection{SAVANNAH RIVER SITE DESCRIPTION}

Early black and white photography shows a predominantly agricultural landuse rich with bottomland hardwoods commonly associated with riparian communities. Carolina Bays, wetland features unique to this geographic location, dotted the landscape. Many were ditched by landowners to increase cropland acreage. Several small communities existed within what is now SRS, but the area was best described as rural.

Since the inception of SRS, the landscape has evolved to include a dense transportation network. The small communities were removed from the site and five nuclear production reactors and other support facilities were erected. Most recently, facilities to accommodate storage and restoration practices have been added. Much of the site was converted to pine production. Carolina Bays are still numerous, but there is noticeable change along the stream channel floodplains and the Savannah River Swamp primarily attributed to thermal effluent of production reactors (Tinney et al., 1986; Gladden et al., 1985). Several large cooling ponds were developed along Steel Creek (L Lake) and Lower Three Runs Creek (Par Pond) to reduce effects of cooling water discharge. They have had an impact on the appearance of the landscape and have increased the acreage of open water.

\subsection{METHODOLOGY}

Techniques used to quantify production impact on the environment at the SRS include gamma detection surveys, multispectral scanner surveys, aerial photography missions, and the time-intensive ground truthing procedures that accompany them. All contribute to the effort aimed at measuring environmental changes at SRS and are potential elements for a sitewide GIS. It was felt that stereoscopic photointerpretation of the early aerial photography might provide thorough documentation for illustrating pre-SRS activity.

\subsection{Stereoscopic Photographic Interpretation}

Black and white aerial photographs were acquired in March, April, and May 1943 at scale 1:10000, and in January and May 1951 at scale 1:20000. Figure 1 shows the flight lines for the multidate photography used in the photographic interpretation process. While studies have shown that acquisition of both Spring and Fall color infrared photography yields optimum results for delineating specific wetland species (Shima et al., 1976; Best $e t$ al., 1981; and Howland, 1980), success in mapping wetland communities using black and white film has been documented (Steffensen et al., 1976). 
Approximately 300 aerial photographs (See Appendix A) were analyzed with a Bausch and Lomb stereoscope mounted on a Richards light table using standard photointerpretation techniques (Avery, 1968; Paine, 1981). The classification scheme presented in Appendix B was previously used for the sitewide land cover classification from which the recent wetlands data layer information was extracted (Christel and Guber, 1994). The scheme was also used in the historical wetlands interpretation to promote compatibility among the existing data layers. Wetland information was manually traced directly from the black and white aerial photographs onto removable transparent mylar. Interpretation was limited to the center of the photographs to minimize distortion effects that increase toward the edge of a photograph. Terrain relief aided in identifying lowland areas or upland depressions where wetlands are most likely to occur. Although variations in tree maturity, stand densities, and stand species composition promoted confusion among the forested wetland classes, tonal and textural differences in the photography helped to distinguish stands of Bottomland Hardwoods from Swamp Forest.

\subsection{Geographic Information System Processing}

After the photographic interpretation task was completed, a map containing road network, hydrographic, and hydric soils information at scale 1:20000 was generated from the USGS digital line graph, current landuse, and soils data layers, respectively. The mylars were removed and placed under the hydrography map and the wetland class information, in the form of polygons, was manually transferred onto the map sheet. The 1943 data were reduced to scale 1:20000 to facilitate data transfer. Each polygon was digitized and labeled to wetlands class codes using ARC/INFO VAX Version 5.1 (ESRI, 1987) software interfaced with a CalComp Series 9100 digitizing tablet. RMS errors did not exceed 2 meters. The data layer was systematically reviewed, edited and replotted, and checked once again against the photographs. Polygons from each class were randomly selected and compared to the classification scheme to assure consistent class labeling. Refer to the data dictionary for coverage HWET in Appendix $\mathrm{C}$ for a description of the attributes associated with the historical wetlands data layer.

Several versions of color-coded and black and white map products were generated. Sitewide and 7.5-minute quadrangle area statistics were calculated to compare with those derived from the recent wetlands data layer. The Pen Branch Delta was also mapped to illustrate the changes that have occurred in the Bottomland Hardwood class representation. Examples of these and several other map products are presented in the following section and in Appendix D. 


\subsection{RESULTS}

Although unrectified photographs were used as the base data, the photointerpretation process resulted in a historical wetlands data layer that can be used with existing data layers. When looking at specific elements in the landscape, good agreement exists between the historical wetlands land cover classification and the current wetlands land cover classification. There is also good agreement between the historical wetlands classes and the hydric soils class in the existing soils data layer. Figure 2 shows the results of the photointerpretation of historical aerial photography.

Table 1 shows a sitewide estimate of area approximations and frequency of occurrence (in parenthesis) for six pre-and post-SRS wetland classes in hectares. Estimates indicate that approximately 314 hectares of wetlands have been lost. The largest losses appear to be in the Bottomland Hardwood and Bottomland Scrub Shrub classes. Combined, the losses are of the same magnitude as the gain in Open Water. Comparison of Figures 2 and 3 indicates that this relationship has been verified through the photointerpretation process. The gain in Open Water can be attributed to the creation of several large cooling ponds. The Swamp Forest community area estimates are within 10 hectares and exhibit the least amount of change with site activity. The Pen Branch Delta, shown in Figure 4, is a good example of an area that has exhibited a decrease in Bottomland Hardwoods and increase in Open Water, and a maintenance of the Swamp Forest acreage over time. Loss of the Drained Wetland/Ditched community may be attributable to a shift in classification to the Emergent Wetland class which has increased with site activity. This may be due to the reestablishment of some of the Carolina Bays after they were drained.

\begin{tabular}{|c|c|c|c|}
\hline Wetland Class & Pre-Activity & Post-Activity & Change \\
\hline Bottomland Hardwood & $15,077(287)^{b}$ & $13,825 \quad(869)$ & $-1,252$ \\
\hline Bottomland Scrub Shrub & $1,548(186)$ & $843 \quad(359)$ & -705 \\
\hline Swamp Forest & $2,341 \quad(41)$ & $2,331 \quad(83)$ & -10 \\
\hline Emergent Wetland & $408(216)$ & $519 \quad(102)$ & +111 \\
\hline Drained Wetland/Ditched ${ }^{a}$ & $320(134)$ & (43) & -235 \\
\hline Open Water & $438 \quad(37)$ & $2,215 \quad(150)$ & $+1,777$ \\
\hline Total & $20,132(901)$ & $19,818(1,606)$ & -314 \\
\hline
\end{tabular}

ancludes Carolina Bays

b Number of incidences of class occurance 


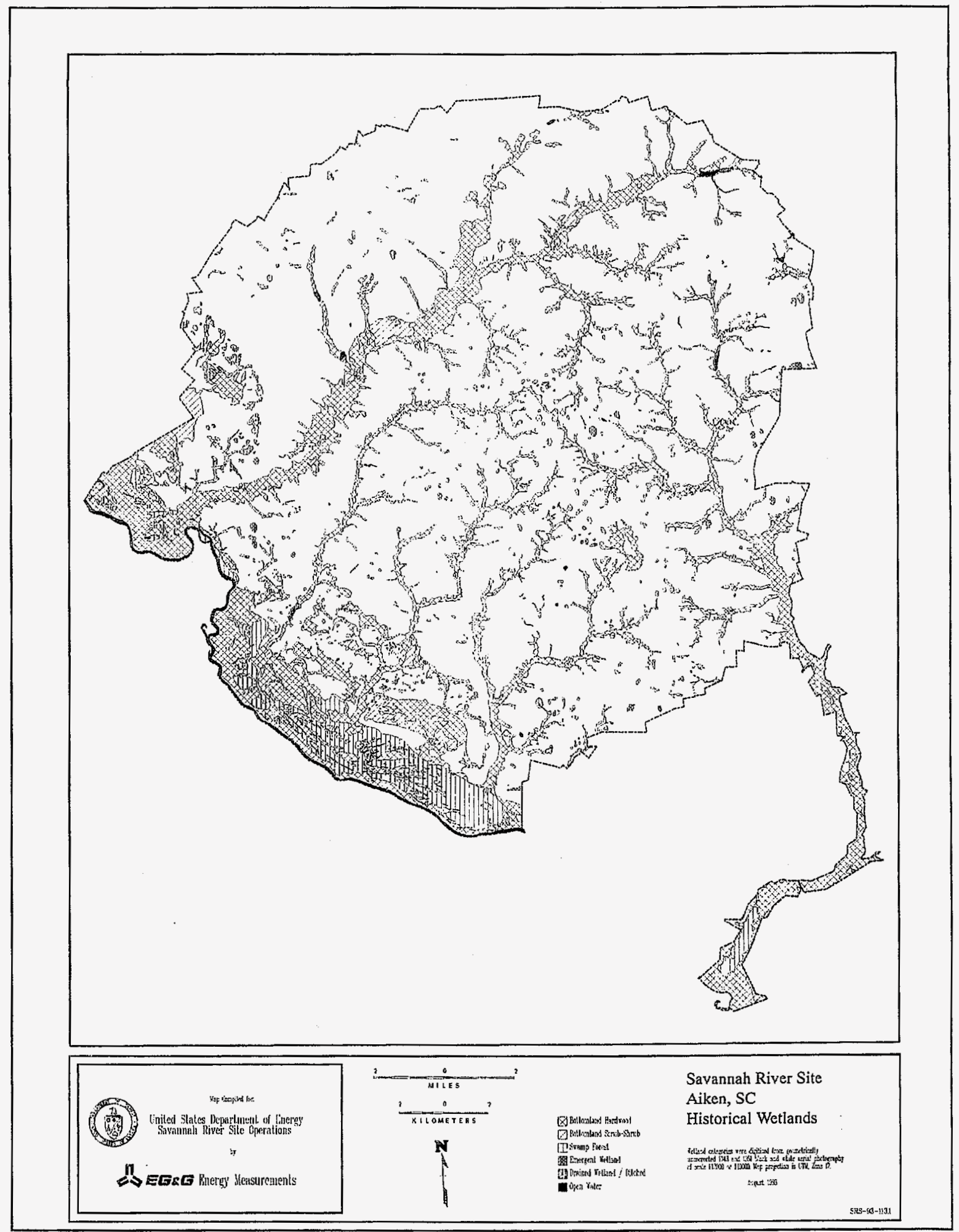

FIGURE 2. HISTORICAL WETLANDS MAP (SRS-93-113.l) INTERPRETED FROM 1943 AND 195I BLACK AND WHITE HISTORICAL PHOTOGRAPHY 


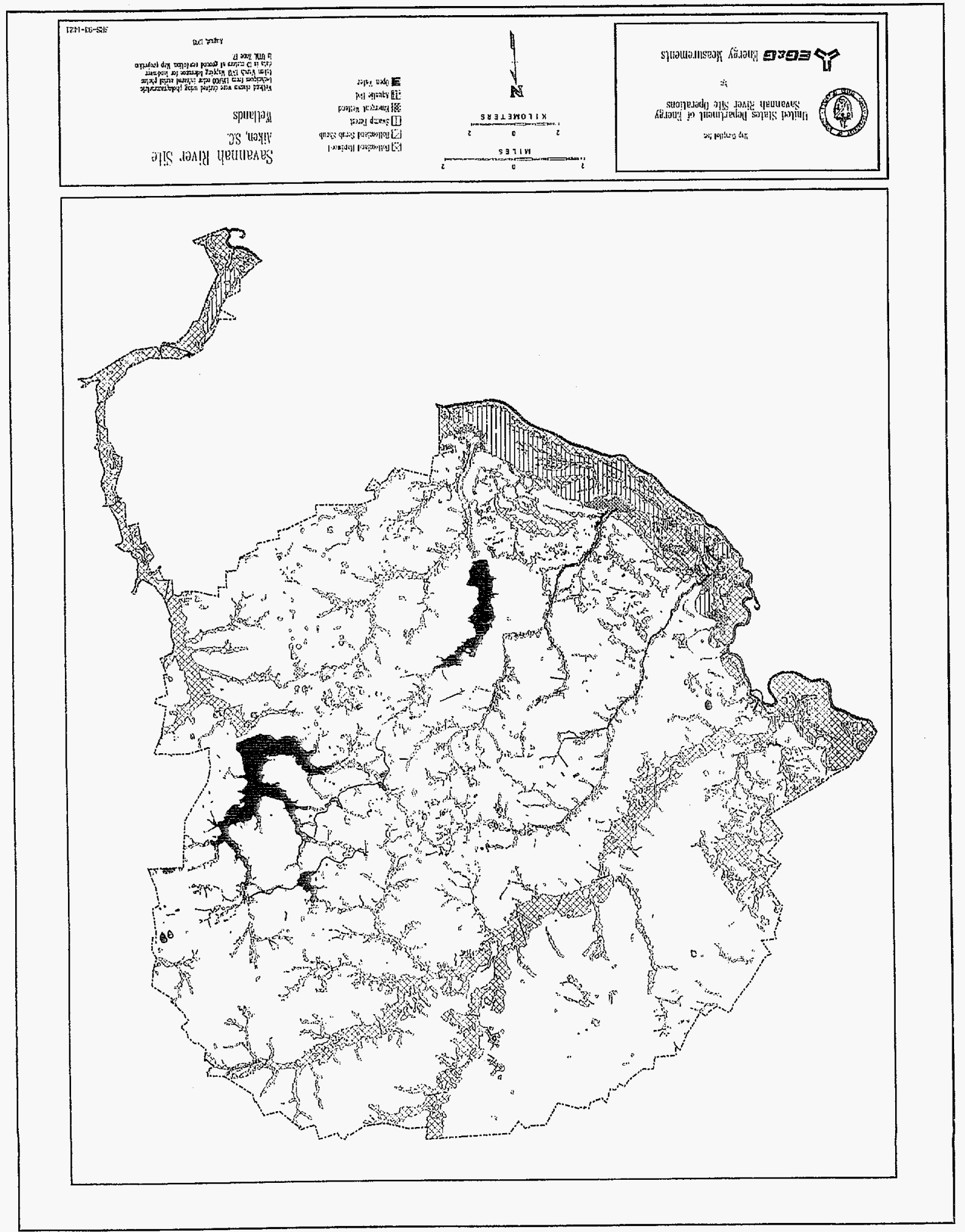




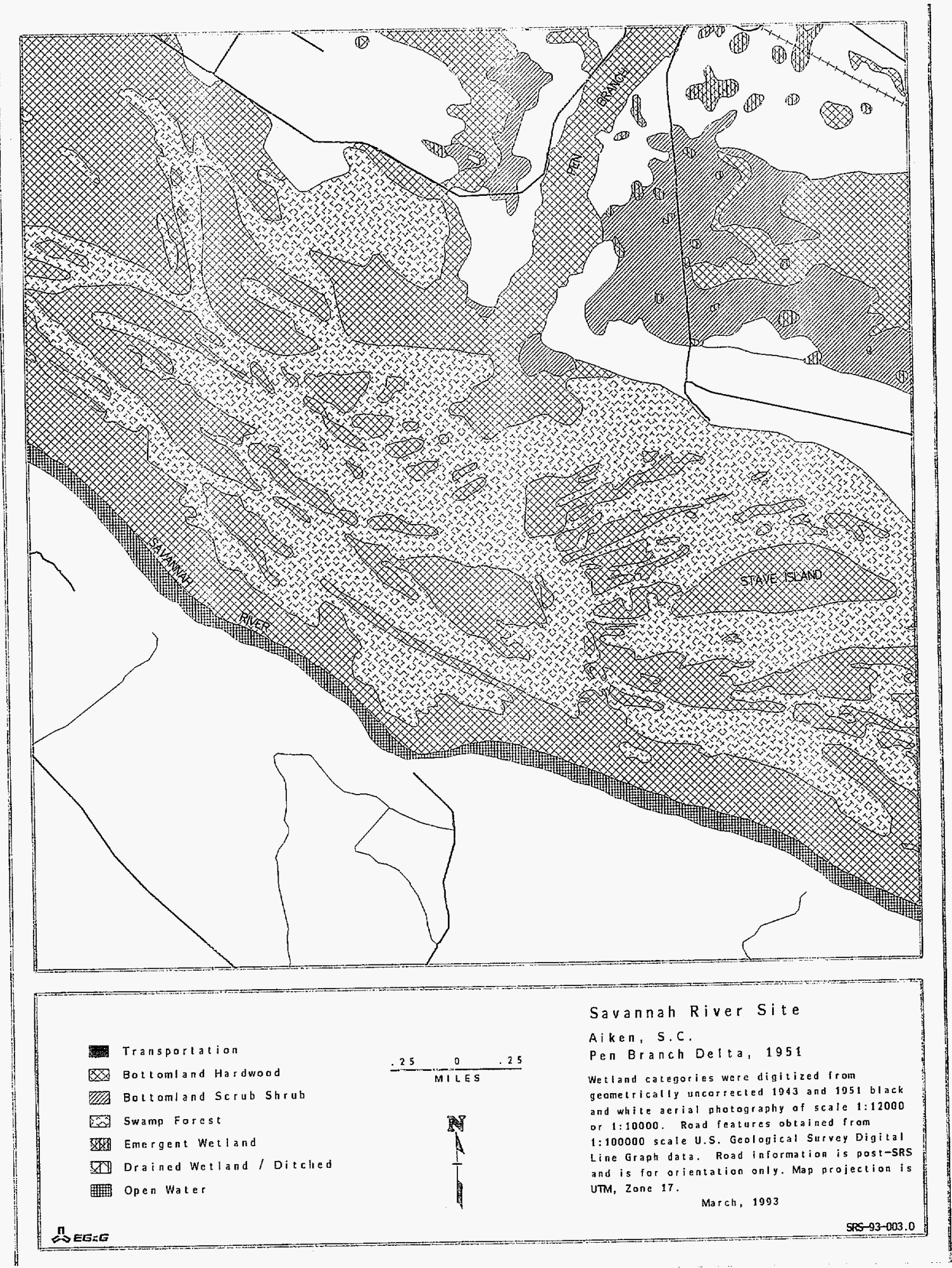

FIGURE 4. PEN BRANCH DELTA WETLAND CLASS MAP (SRS-93-003.0) AS INTERPRETED FROM HISTORICAL PHOTOGRAPHY 
Table 2 describes estimated wetland class areas by $7.5^{\prime}$ quadrangles in 1951 . Black and white versions of these historical maps can be found in Appendix D. Table 3 describes the estimated net gain and loss of wetland class areas by quadrangle based on the 1951 and 1989 wetland data layers. Recent wetland estimates are given in Christel and Guber, 1994. Note that the small differences between the change values in Table 1 and net gains and losses in Table 3 are due to roundoff error. Futhermore, the differences between estimated loss values in the Drained Wetland/Ditched class in Tables 1 and 3 can be accounted for in the differences in the estimated gain values of Open Water. This suggests that several occurrences of the Drained Wetland/Ditched class may have been identified as Open Water in the recent (1989) wetlands sitewide area estimates.

\begin{tabular}{|c|c|c|c|c|c|c|c|}
\hline \multirow{2}{*}{$\begin{array}{c}\text { USGS } \\
\text { Quadrangle } \\
\text { Map }\end{array}$} & \multicolumn{6}{|c|}{ Historical Wetland Classes } & \multirow[b]{2}{*}{$\begin{array}{c}\text { Total } \\
\text { Hectares }\end{array}$} \\
\hline & $\begin{array}{l}\text { Bottomland } \\
\text { Hardwood }\end{array}$ & $\begin{array}{l}\text { Bottomland } \\
\text { Scrub Shrub }\end{array}$ & $\begin{array}{l}\text { Swamp } \\
\text { Forest }\end{array}$ & $\begin{array}{l}\text { Emergent } \\
\text { Wetland }\end{array}$ & $\begin{array}{c}\text { Drained } \\
\text { Wetland/Ditched }^{\mathrm{a}}\end{array}$ & $\begin{array}{l}\text { Open } \\
\text { Water }\end{array}$ & \\
\hline Girard & 563.8 & 26.2 & 961.2 & - & - & 93.2 & $1,644.4$ \\
\hline Girard NE & $1,868.7$ & 39.4 & - & 38.0 & 90.3 & 11.4 & $2,047.8$ \\
\hline Girard NW & $3,552.5$ & 577.7 & 889.5 & 152.0 & 49.6 & 47.8 & $5,269.1$ \\
\hline Jackson & 376.2 & 257.0 & - & 52.3 & 72.4 & - & 757.9 \\
\hline Long Branch & 94.5 & 16.4 & 一 & 28.1 & 21.7 & 8.0 & 168.7 \\
\hline Martin & 639.3 & 31.5 & 14.9 & 一 & 一 & 一 & 685.7 \\
\hline Millet & 496.4 & 8.9 & 207.2 & 10.1 & - & 13.6 & 736.2 \\
\hline New Ellenton & 5.3 & - & - & - & - & - & 5.3 \\
\hline New Ellenton SE & $2,136.0$ & 149.0 & - & 68.4 & 42.8 & 27.5 & $2,423.7$ \\
\hline New Ellenton SW & $2,215.0$ & 324.6 & - & 38.4 & 42.0 & 16.3 & $2,636.3$ \\
\hline Shell Bluff Landing & $2,036.9$ & 47.3 & 267.9 & 10.9 & 0.7 & 215.8 & $2,579.5$ \\
\hline Snelling & 894.1 & 52.7 & - & 8.9 & - & - & 955.7 \\
\hline Windsor & 198.4 & 17.4 & - & 0.5 & - & 4.6 & 220.9 \\
\hline Total & $15,077.1$ & $1,548.1$ & $2,340.7$ & 407.6 & 319.5 & 438.2 & $20,131.2$ \\
\hline
\end{tabular}

ancludes area statistics for Carolina Bays

Referring to Table 1, if one considers the frequency of occurrence for each wetland class when looking at the total area for each class, the numbers suggest that the landscape has become more fragmented since 1951. For example, Swamp Forest has remained at roughly 2300 hectares. In 1951, this acreage was comprised of 41 separate stands. In 1989, the area representing Swamp Forest was comprised of 83 separate stands. Bottomland Hardwood and Bottomland Scrub Shrub communities have lost acreage since 1951 but the number of separate stands has increased substantially. As Table 4 shows, minimum and maximum area values for these three forested wetland classes were notably larger in 1951 when compared to recent values, indicating again that the stands were 
expansive and that there were fewer of them prior to site activity. Causes of this perceived fragmentation could include natural invasion of a species, man-made disturbances, or improvement in the quality of photographic methods used in the recent aerial surveys. The more recent surveys were acquired seasonally over the last few years and included color infrared photography. However, the tonal quality of the older black and white photography was very good and at a scale that was very easy to interpret. Given the development of the road network to support SRS activities, man-made disturbances may play some role in the apparent decrease in the average minimum and maximum areas for several of the classes as well as the increases in their frequency of occurrence. Increased fragmentation of the landscape can affect the distribution of natural species and must be considered in reclamation and restoration planning.

Of the three nonforested wetland classes, the Emergent Wetland and Open Water classes exhibited an increase in acreage. The increase in Open Water acreage is attributed to the creation of large cooling ponds. As mentioned earlier, the increase in Emergent Wetland acreage and the decrease in Drained Wetland/Ditched acreage may be attributable to the reestablishment of Carolina Bays.

Table 3. Estimates of Net Gain or Loss of Wetland Class Areas by Quadrangle Between 1951 and 1989 in Hectares

\begin{tabular}{|c|c|c|c|c|c|c|c|}
\hline $\begin{array}{c}\text { USGS } \\
\text { Quadrangle } \\
\text { Map }\end{array}$ & $\begin{array}{l}\text { Bottomland } \\
\text { Hardwood }\end{array}$ & $\begin{array}{l}\text { Bottomland } \\
\text { Scrub Shrub }\end{array}$ & $\begin{array}{l}\text { Swamp } \\
\text { Forest }\end{array}$ & $\begin{array}{c}\text { Emergent } \\
\text { Wetland }\end{array}$ & $\begin{array}{c}\text { Drained } \\
\text { Wetland/Ditched }^{\mathrm{a}}\end{array}$ & $\begin{array}{l}\text { Open } \\
\text { Water }\end{array}$ & $\begin{array}{c}\text { Total } \\
\text { Hectares }\end{array}$ \\
\hline Girard & -105.2 & +26.8 & +9.8 & +58.4 & - & -0.5 & -10.7 \\
\hline Girard NE & -286.0 & +128.8 & - & +2.1 & -81.2 & +480.6 & +244.3 \\
\hline Girard NW & $-1,198.7$ & -330.1 & -44.3 & +103.6 & -32.1 & +535.2 & -966.4 \\
\hline Jackson & +362.8 & -217.2 & +0.9 & -52.3 & -72.4 & 一 & +21.8 \\
\hline Long Branch & +38.8 & -9.4 & 一 & -22.5 & +4.9 & +3.7 & +15.5 \\
\hline Martin & -16.5 & -23.7 & +4.7 & - & - & +2.4 & -33.1 \\
\hline Millet & -71.1 & -1.9 & +4.5 & -0.7 & - & +37.5 & -31.7 \\
\hline New Ellenton & +4.0 & - & - & - & - & 一 & +4.0 \\
\hline New Ellenton SE & -157.4 & -64.6 & - & -39.4 & +27.3 & +659.3 & +425.2 \\
\hline New Ellenton SW & +101.6 & -196.3 & - & +1.4 & -40.7 & +4.1 & -129.9 \\
\hline Shell Bluff Landing & -249.6 & +48.3 & +15.2 & +65.4 & -0.7 & +17.8 & -103.6 \\
\hline Snelling & +58.1 & -49.1 & - & -5.0 & +0.8 & +0.6 & +5.4 \\
\hline Windsor & +266.3 & -17.4 & - & +0.4 & - & -4.6 & +244.7 \\
\hline Net Gains and Losses & $-1,252.9$ & -705.8 & -9.2 & +111.4 & -194.1 & $+1,736.1$ & -314.5 \\
\hline
\end{tabular}

a Includes area statistics for Carolina Bays 


\begin{tabular}{|l|r|r|r|r|}
\hline \multicolumn{2}{|c|}{ Table 4. Minimum and Maximum Areas for Pre- and Post-SRS Wetland } \\
Classes in Hectares \\
\cline { 2 - 5 } Wetland Class & \multicolumn{2}{|c|}{ 1951 Area } & \multicolumn{2}{c|}{ 1989 Area } \\
\cline { 2 - 5 } & Min. & \multicolumn{1}{c|}{ Max. } & Min. & \multicolumn{1}{c|}{ Max. } \\
\hline Bottomland Hardwood & .036 & $4,374.956$ & .002 & $1,054.745$ \\
Bottomland Scrub Shrub & .274 & 187.906 & .138 & 69.143 \\
Swamp Forest & .158 & $1,905.260$ & .006 & $1,687.035$ \\
Emergent Wetland & .066 & 15.657 & .139 & 110.021 \\
Drained Wetland/Ditched & .150 & 20.824 & .212 & 9.330 \\
Open Water & .127 & 348.504 & .119 & 878.475 \\
\hline
\end{tabular}

ancludes Carolina Bays

\subsection{DISCUSSION AND RECOMMENDATIONS}

This analysis has demonstrated the utility of GIS technology in environmental assessment. With the addition of historical data and other ancillary data that can be tied to the database by geographic coordinates, resource analysts can extract and investigate specific regions and themes of interest in a timely manner. The GIS becomes increasingly comprehensive and useful as more information becomes available and is incorporated into the database.

In this study, the net gains or losses to specific wetland class areas were estimated using a combination of standard photointerpretation techniques and GIS analysis. Simple statistics were generated to determine how wetland class distributions have changed since the startup of SRS for the sitewide coverage as well as by $7.5^{\prime}$ quadrangle. The locations where changes have occurred over time for each class have been determined. Results from these investigations can be used to aid resource managers in defining their questions regarding restoration needs and procedures.

An important factor in database development is an understanding of the overall quality of the data sources. Sources take on many forms and are not always of the integrity analysts would like, but they are unique pieces of information that could add considerably to the usefulness of GIS analyses. While incorporation into the database may not seem ideal, adequately maintained quality assurance records would permit prospective GIS users to weigh the advantages of incorporating such a data layer into their analyses against eliminating it altogether. One common example of this is the use of unrectified aerial photography. Depending on the extent of the area of study, the photorectification process can be costly and deemed as an unnecessary expenditure for a specific 
task. Skilled interpreters can decrease the effects of distortion by restricting interpretation to the center of the photography, or nadir, as was done in this study. Comparison to other related data layers, such as soil type or transportation, can give a fair estimate as to the spatial integrity of data obtained in this manner. When accuracy is a critical issue, it becomes necessary to ensure that data are of the best quality available. Temporal analysis of digital orthophotographs derived from high resolution color infrared film is recommended if highly accurate wetland classifications are desired. Industry has recognized the need for cost-effective methods of photorectification and the technology is becoming more affordable as time passes.

Finally, while automation of old methods is almost always expensive due to capital equipment expenditures and the investment in man hours needed to convert data, the flexibility and speed afforded by the technology outweighs the costs in most environmental applications of the magnitude required for SRS. Centralization of extensive data layers tied together by geographic location can be used for cost-effective analytical and spatial investigations. 


\section{APPENDIX A}

\section{HISTORICAL AERIAL PHOTOGRAPHY}


Aerial photographs used for this study are listed by date below. These photographs can be found in the archives of SRS ESS or EG\&G Energy Measurements, Inc., in Las Vegas, Nevada.

\begin{tabular}{|c|c|c|c|}
\hline $\begin{array}{c}\text { Flight } \\
\text { Line }\end{array}$ & Photo ID & Scale & Date \\
\hline 1 & OR-7H-3 thru OR-7H-12 & $1: 20000$ & $5-10-51$ \\
\hline 2 & OR-6H-192 thru OR-6H-206 & $1: 20000$ & $5-09-51$ \\
\hline \multirow[t]{2}{*}{3} & OU-6H-122 thru OU-6H-127 & $1: 20000$ & $5-08-51$ \\
\hline & OR-6H-128 thru OR-6H-139 & & \\
\hline \multirow[t]{2}{*}{4} & OR-6H-99 thru OR-6H-109 & $1: 20000$ & $5-08-51$ \\
\hline & OU-6H-110 thru OU-6H-117 & & \\
\hline \multirow[t]{2}{*}{5} & OU-6H-19 thru OU-6H-30 & $1: 20000$ & $5-08-51$ \\
\hline & OR-6H-31 thru OR-6H-39 & & \\
\hline \multirow[t]{3}{*}{6} & OR-5H-210 thru OR-5H-217 & $1: 20000$ & $5-08-51$ \\
\hline & OU-5H-218 thru OU-5H-219 & & \\
\hline & OU-6H-2 thru OU-6H-13 & & \\
\hline \multirow[t]{2}{*}{7} & OU-5H-124 thru OU-5H-138 & $1: 20000$ & $5-08-51$ \\
\hline & OR-5H-139 thru OR-5H-144 & & \\
\hline \multirow[t]{3}{*}{8} & OR-5H-95 thru OR-5H-99 & $1: 20000$ & $5-08-51$ \\
\hline & OU-5H-100 thru OU-5H-102 & & \\
\hline & OS-5H-113 thru OS-5H-116 & & \\
\hline 9 & OU-4H-206 thru OU-4H-215 & $1: 20000$ & $5-07-51$ \\
\hline \multirow[t]{2}{*}{10} & OR-4H-157 thru OR-4H-158 & $1: 20000$ & $5-07-51$ \\
\hline & OU-4H-159 thru OU-4H-174 & & \\
\hline \multirow[t]{3}{*}{11} & OR-4H-90 & $1: 20000$ & $5-06-51$ \\
\hline & OU-4H-91 thru OU-4H-107 & & \\
\hline & OS- $4 \mathrm{H}-108$ thru OS-4H-109 & & \\
\hline 12 & OU-2C-95 thru OU-2C-106 & $1: 10000$ & $3-30-43$ \\
\hline \multirow[t]{2}{*}{13} & OR-3C-197 thru OR-3C-204 & $1: 10000$ & $5-01-43$ \\
\hline & OU-8C-15 thru OU-8C-36 & $1: 10000$ & $5-13-43$ \\
\hline \multirow[t]{2}{*}{14} & OU-2C-153 thru OU-2C-155 & 1:10000. & 4-03-43 \\
\hline & OS-2C-151 thru OU-2C-152 & & \\
\hline 15 & OS-4H-179 thru OS-4H-183 & $1: 10000$ & $5-07-51$ \\
\hline 16 & OS-4H-111 thru OS-4H-113 & $1: 10000$ & $5-06-51$ \\
\hline \multirow[t]{2}{*}{17} & OU-4H-17 thru OU-4H-18 & $1: 10000$ & $5-05-51$ \\
\hline & OS- $4 \mathrm{H}-13$ thru OU- $4 \mathrm{H}-16$ & & \\
\hline 18 & OR-3C-56 thru OR-3C-59 & $1: 10000$ & $5-01-43$ \\
\hline 19 & $35-903$ thru $35-908$ & $1: 10000$ & $1-08-51$ \\
\hline
\end{tabular}




\section{Flight}

Line

20

21

22
Photo ID

36-873 thru 36-877

36-1191 thru 36-1196

37-829 thru 37-836

38-800 thru 38-806
Scale

1:10000

1:10000

1:10000

1:10000
Date

1-08-51

1-12-51

1-05-51

1-05-51 
APPENDIX B

WETLAND CLASS DESCRIPTIONS 
Wetlands are those areas in which the water table is at, near, or above the land surface for a significant part of most years. Wetland areas are frequently associated with topographic lows. Examples of wetlands include marshes, mud flats, and swamps situated on the shallow margins of lakes, ponds, streams, and man-made impoundments such as reservoirs.

FORESTED WETLAND: Characterized by woody vegetation with a canopy closure of 25 percent or more and where moisture is relatively abundant, particularly along rivers or depressions.

Swamp Forest: Comprised of forests that are inundated most or all of the year; characterized by Bald Cypress, Tupelo Gum, and Water Gum that are at least 6 meters tall. Variation within the swamp is controlled by the depth and duration of flooding. In some areas of the swamp near the stream deltas, regions within the swamp forest have died, but a 25 percent canopy of dead trees remains. These areas are mapped as Swamp Forest.

Bottomland Hardwood: Includes contiguous groups of deciduous hardwoods at least 6 meters tall located in stream floodplains, water table outcroppings, or depressional areas prone to seasonal soil saturation. Bottomland Hardwoods occur in areas where flooding is of limited depth and/or duration.

Scrub-Shrub: Includes areas dominated by woody vegetation averaging less than 6 meters tall in wet areas with less than 25 percent tree cover and with a predominance of scrubby growth. The species include true shrubs, young trees, and trees or shrubs that are small or stunted because of environmental conditions.

NONFORESTED WETLAND: Dominated by wetland herbaceous vegetation or non-vegetated wetland areas.

Emergent Wetland: Characterized by erect, rooted, herbaceous hydrophytes, excluding mosses and lichens. Emergent Wetland occurs in wet areas with less than 25 percent tree cover and with at least 50 percent vegetation cover and either persistent or nonpersistent emergent vegetation.

Aquatic Bed: Represented by a diverse group of plant communities that require surface water for optimum growth and reproduction. They are best developed in relatively permanent water or under conditions of repeated flooding.

OPEN WATER: Includes rivers, streams, canals and open water areas within the swamp; nonflowing naturally enclosed bodies of water, including regulated natural lakes but excluding reservoirs; ponds include small, shallow, permanent or intermittent water bodies. 
APPENDIX C

HISTORICAL WETLANDS DATA DICTIONARY 


\section{Metadata Information for Historical Wetlands 1}

Identification_Information:

Data_Set_Identity: Hwet

Identification_Code: Not applicable

Data_Set_Description: Wetland data interpreted from historical black and white aerial photographs of SRS intended to be used as a baseline wetland theme in the SRS GIS database.

Theme: Wetlands prior to 1952

Data_Currentness_and_Quality_Summary

Beginning_Date_of_Information_Data: 1943

Ending_Date_of_Information_Data: 1951

Thematic_Quality

Quantitative_Thematic_Accuracy_Assessment: Not performed

Qualitative_Thematic_Accuracy_Assessment: Based on random sampling performed by several analysts, it has been evaluated as accurate.

Logical_Consistency: Very good

Completeness: Total sitewide coverage achieved using multiple dates of aerial photography.

Horizontal_Positional_Quality

Quantitative_Horizontal_Positional_Accuracy_Assessment

Horizontal_Positional_Accuracy: Calculated control during registration was less than 7 meters.

Unrectified photography diminishes the accuracy.

Horizontal_Positional_Accuracy_Explanation: Based upon digitization and maximum mapping distances for photointerpretation

Qualitative_Horizontal_Positional_Accuracy_Assessment: Very good agreement with DLG road and hydric soil data.

Vertical_Positional_Quality: Not applicable

Cloud_Cover: $0 \%$

Bounding_Coordinates

West_Bounding_Coordinate: 422511.125

East_Bounding_Coordinate: 459312.781

North_Bounding_Coordinate: 696024.312

South_Bounding_Coordinate: 653395.375

Browse_Graphic

Browse_Graphic_File_Name: hwet.plt

Browse_Graphic_File_Description: 1:24000 scale color sitewide SRS historical wetlands data layer.

Browse_Graphic_File_Type: Postscript

Data_Set_Citation: Historical Wetlands Mapping and GIS Processing for the Savannah River Site Database, Christel, L.M., EGG 11265-1018, August 1994.

\footnotetext{
${ }^{1}$ Format referenced to Spatial Metadata Content Standard initially developed by ASTM in 1990 for field data collection.
} 
Historical Database Development in Support of Wetland Remediation at the

Savannah River Site, Christel-Rose, L.M., and H.E. Mackey, Jr., Ph.D. Presented at the ASTM International Symposium on Remote Sensing and GIS for Site

Characterization: Applications and Standards, January 1994, San Francisco,

California.

Native_Data_Set_Environment: Originally created on VAX, was upgraded to Arc/Info 5.0 Unix based Sun OS in SRP/history/wetlands/wet

Use_Restrictions: Data distribution as requested

Access_Restrictions: None

Security_Information

Security_Classification: None

Security_Handling_Description: None

Spatial_Reference:

Native_Spatial_Data_Structure: Vector

Indirect_Spatial_Reference: Projected from geographic to UTM in ARC/INFO

Direct_Spatial_Reference: USGS 7.5' quadrangle maps

Horizontal_Coordinate_System_Definition

Planar

Grid_Coordinate_System

Ūniversal_Transverse_Mercator

UTM_Zone_Number: 17

Vertical_Coordinate_System_Definition: Not applicable

Point/Vector_Object_Information

Point/Vector_Horizontal_Position: Registered USGS quadrangle sheets

Point/Vector_Horizontal_Encoding_Method: Historical wetland labels

Point_Object_Information: None

Vector_Object_Information

Vector_Object_Type: Polygon label points

Vector_Object_Count: 992

Raster_Object_Information: None

Status_Information:

Data_Set_Status: Available

Release_Date: 1993

Maintenance_and_Update_Frequency: As requested

Source_Information:

Source_Identity: Multi-date aerial photography

Source_Contribution: High resolution color and color infrared wetland information 
Processing_History_Information:

Process_Step

Process_Description: Ongoing process developed over several years of review. Please refer to processing logs available at RSL.

Process_Contact: Lynne M. Christel

Entity/Attribute_Information: In addition to the default attributes, area, perimeter, wet\# and wet-ID, the following items were added to the polygon coverage:

Entity_Type

Entity_Type_Label: Polygon

Entity_Type_Definition: Label

Entity_Type_Definition_Source: ARC/INFO

Attribute

Attribute_Label: Code

Attribute_Definition: Wetland code

Attribute_Defintion_Source: Wetland classification scheme. Refer to Appendix B.

Attribute/Entity_Association

EA_Domain_Values:Historical Wetland Class Codes

$10=$ Swamp Forest

11 = Bottomland Hardwood

$12=$ Bottomland Scrub Shrub

$13=$ Emergent Wetland

$15=$ Drained wetland/ditched (often was a Carolina Bay)

$20=$ Open Water

Unrepresentable_Domain: 0

EA_Units_of_Measurement: Integer

Attribute

Attribute_Label: Date

Attribute_Definition: Aerial photography acquisition date

Attribute_Definition_Source: Defined in INFO

Attribute/Entity_Association

EA_Domain_Values: All dates of photography are (mm-dd-yr):

3-30-43

4-03-43

$5-01-43$

5-13-43

$1-05-51$

$1-08-51$

$1-12-51$

$5-05-51$

$5-06-51$ 
$5-07-51$

$5-08-51$

$5-09-51$

$5-10-51$

Unrepresentable_Domain: 0

EA_Units_of_Measurement: Date

Attribute

Attribute_Label: freq

Attribute_Definition: How many incidents of this class occur in the coverage

Attribute_Defintion_Source: STATISTICS in ARC/INFO

Attribute/Entity_Association

EA_Domain_Values: (1-287)

Unrepresentable_Domain: 0

EA_Units_of_Measurement: Integer

Attribute

Attribute_Label: Hectares

Attribute_Definition: Statistical area measurement for historical wetland polygons

Attribute_Defintion_Source: STATISTICS in ARC/INFO

Attribute/Entity_Association

EA_Domain_Values: (0-15077.156)

Unrepresentable_Domain: 0

EA_Units_of_Measurement: Integer

Attribute

Attribute_Label: Bay_no

Attribute_Definition: Carolina Bay identification number that corresponds to Schalles et al., 1989.

Attribute_Definition_Source: Carolina Bays of the Savannah River Plant, Schalles, J.F., R.R. Sharitz, J.W. Gibbons, G.J. Leversee, and J.N. Knox. SRO-NERP-18, DOE Savannah River Plant National Environmental Research Park Program

Attribute/Entity_Association

EA_Domain_Values: (1-194)

Attribute

Attribute_Label: Bay_type

Attribute_Definition: Carolina Bay designation as known or suspected corresponds to Schalles et al., 1989.

Attribute_Definition_Source: Carolina Bays of the Savannah River Plant, (Schalles et al., 1989), SRO-NERP-18, DOE Savannah River Plant National Environmental Research Park Program 
Attribute/Entity_Association

EA_Domain_Values: (1 or 2)

Attribute

Attribute_Label: Bay_name

Attribute_Definition: Carolina Bay as named in Schalles et al., 1989.

Attribute_Definition_Source: Carolina Bays of the Savannah River Plant, (Schalles et al., 1989), SRO-NERP-18, DOE Savannah River.Plant National Environmental Research Park Program

Attribute/Entity_Association

EA_Domain_Values: Character string

Attribute

Attribute_Label: Old_hects

Attribute_Definition: Statistical area measurement for historical Carolina Bays polygons

Attribute_Defintion_Source: STATISTICS in ARC/INFO

Attribute/Entity_Association

EA_Domain_Values: (0-15077.156)

Unrepresentable_Domain: 0

EA_Units_of_Measurement: Integer

Distribution_Information:

Distribution_Contact: Halkard E. Mackey, Jr., Ph.D.

Distribution_Liability: Unknown

Transfer_Options

Media

Non_Digital_Media: Hardcopy plots of coverage

Digital_Media

Transfer_Format: ASCII, TIFF, .E00

Transfer_Size_Information

File Compression_Technique: None

Transfer_Size: .E00 is 3,478,409 bytes

Digital_Transfer_Options: $8 \mathrm{~mm}, 9$ track, optical

Metadata_Reference_Information:

Metadata_Date: June 1994

Metadata_Review_Date: June 1994

Metadata_Future_Review_Date: As the coverage is updated

Metadata_Contact: Lynne M. Christel

Contact_Information:

Contact_Person_Primary

Contact_Organization: Department of Energy's Remote Sensing Laboratory

operated by EG\&G/Energy Measurements, Inc. 
Contact_Person: Lynne M. Christel

Contact_Organization_Primary: Spectral Imaging/Geographic Information System Section

Contact_Position: Scientist

Contact_Mail_Address: P.O. Box 1912

M/S RSL-19

Las Vegas, NV 89125

Contact_Voice_Telephone: (702) 295-8615

Contact_Facsimile_Telephone: (702) 295-8627

Contact_Electronic_Mail: Chri_Im@SGISV0.EGG-EM.COM 


\section{APPENDIX D}

\section{HISTORICAL WETLANDS QUADRANGLE MAPS}




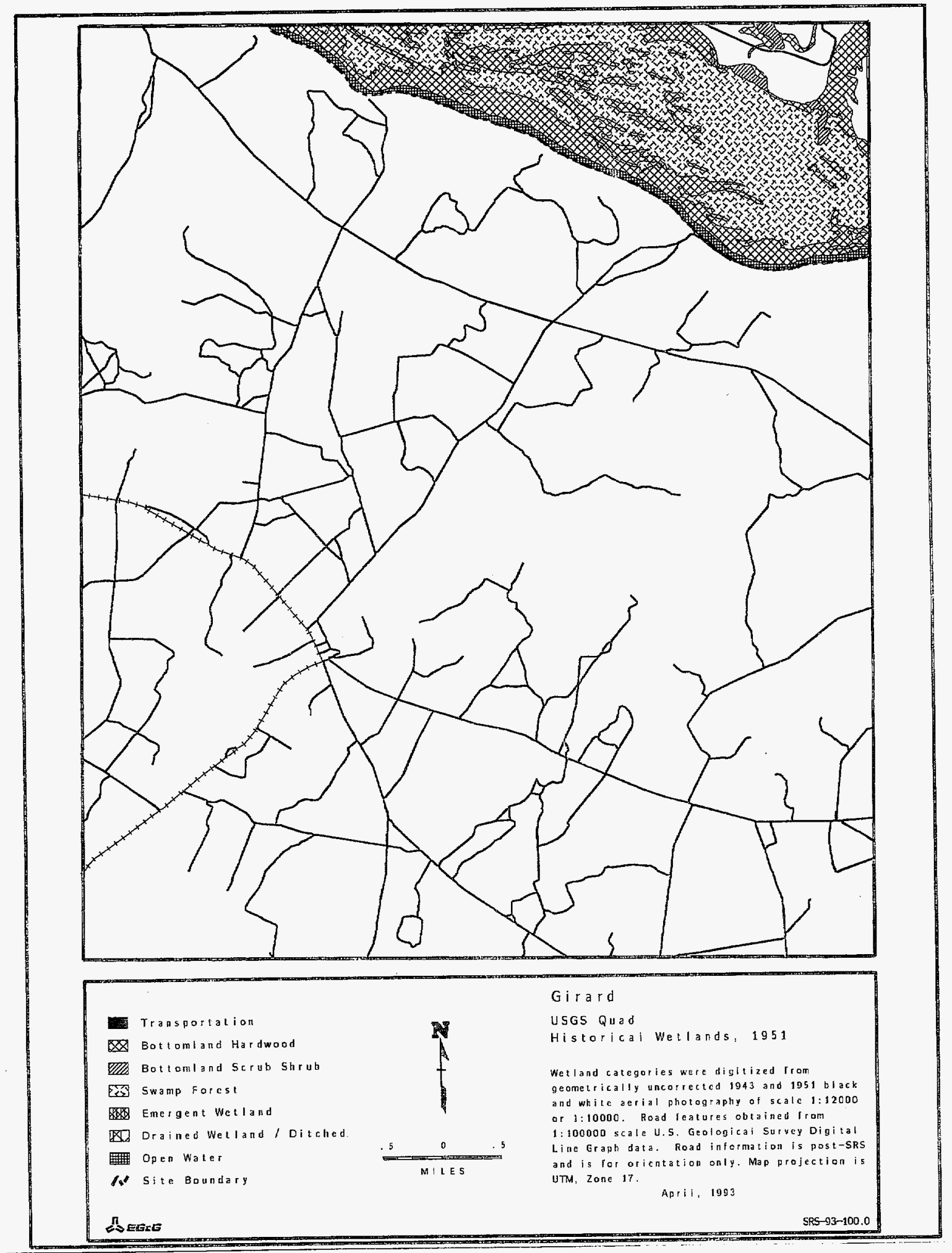



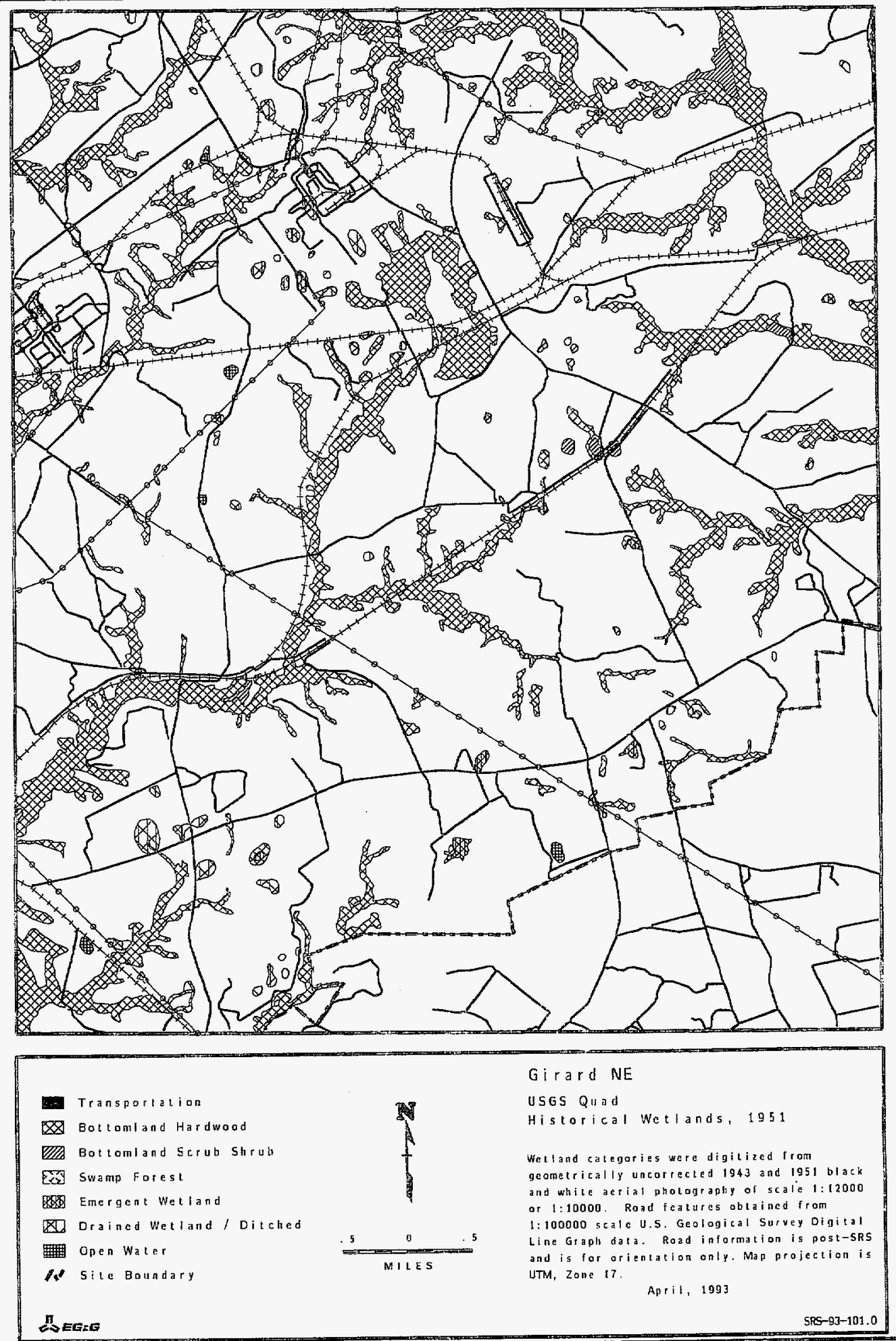


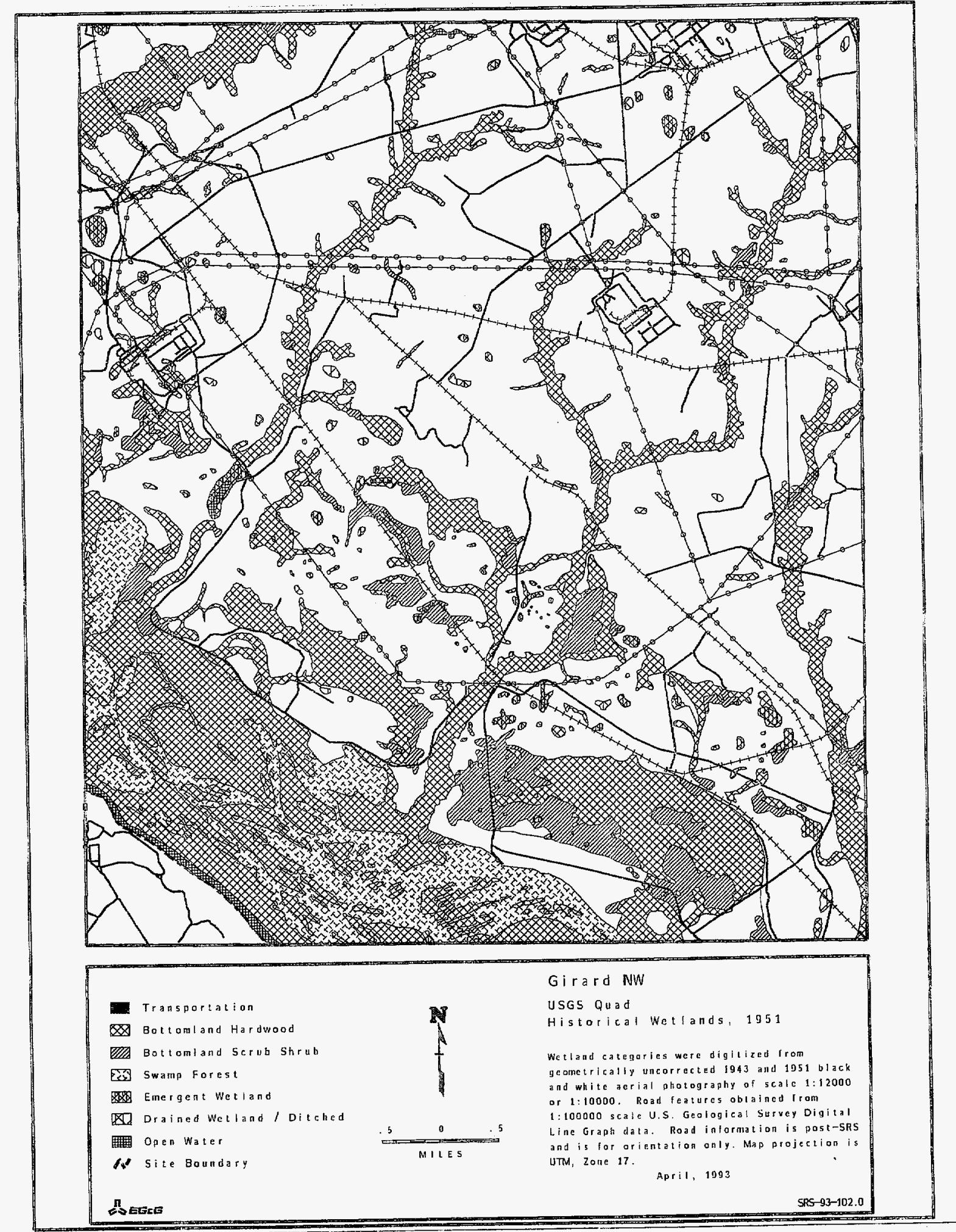




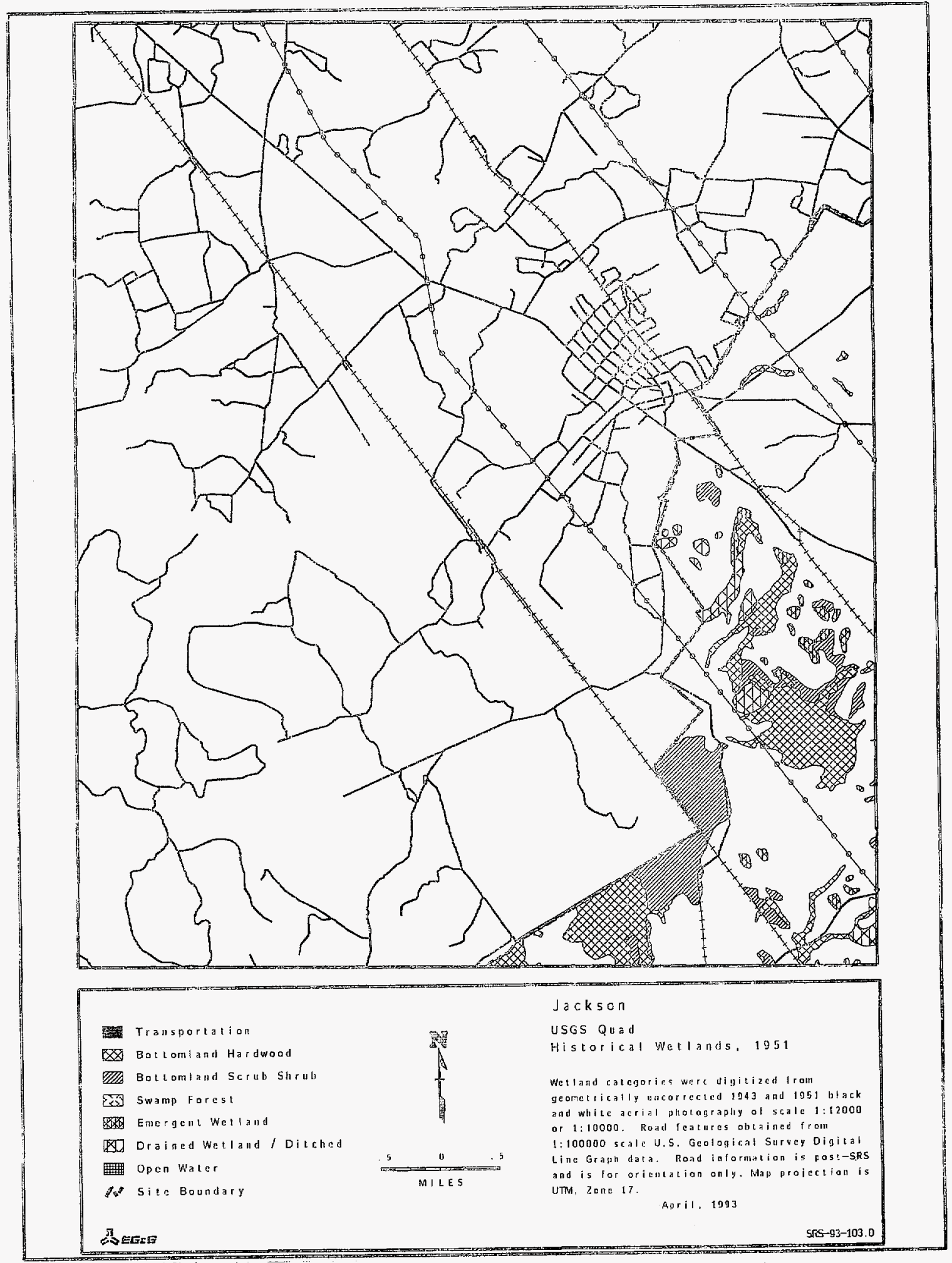




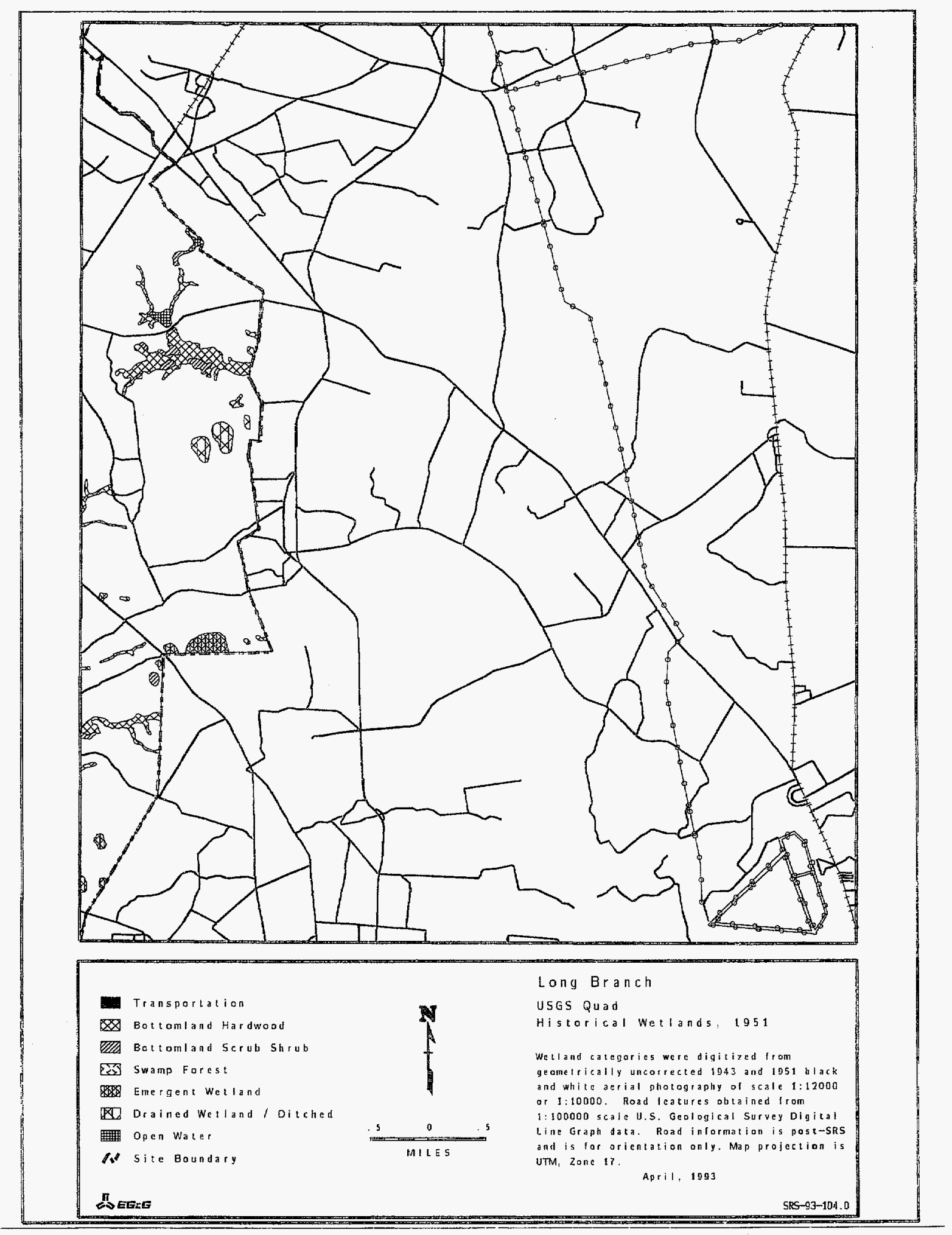




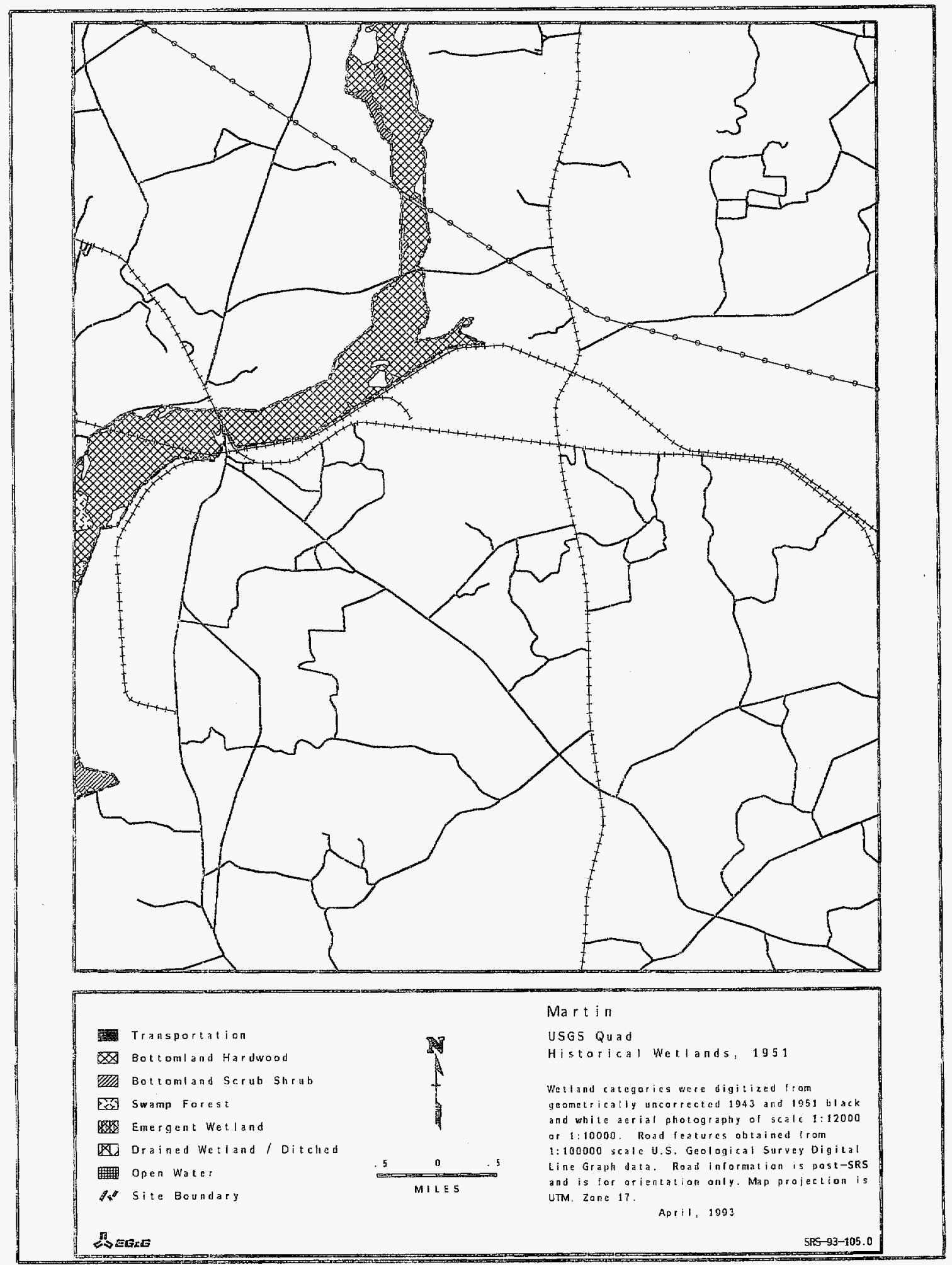




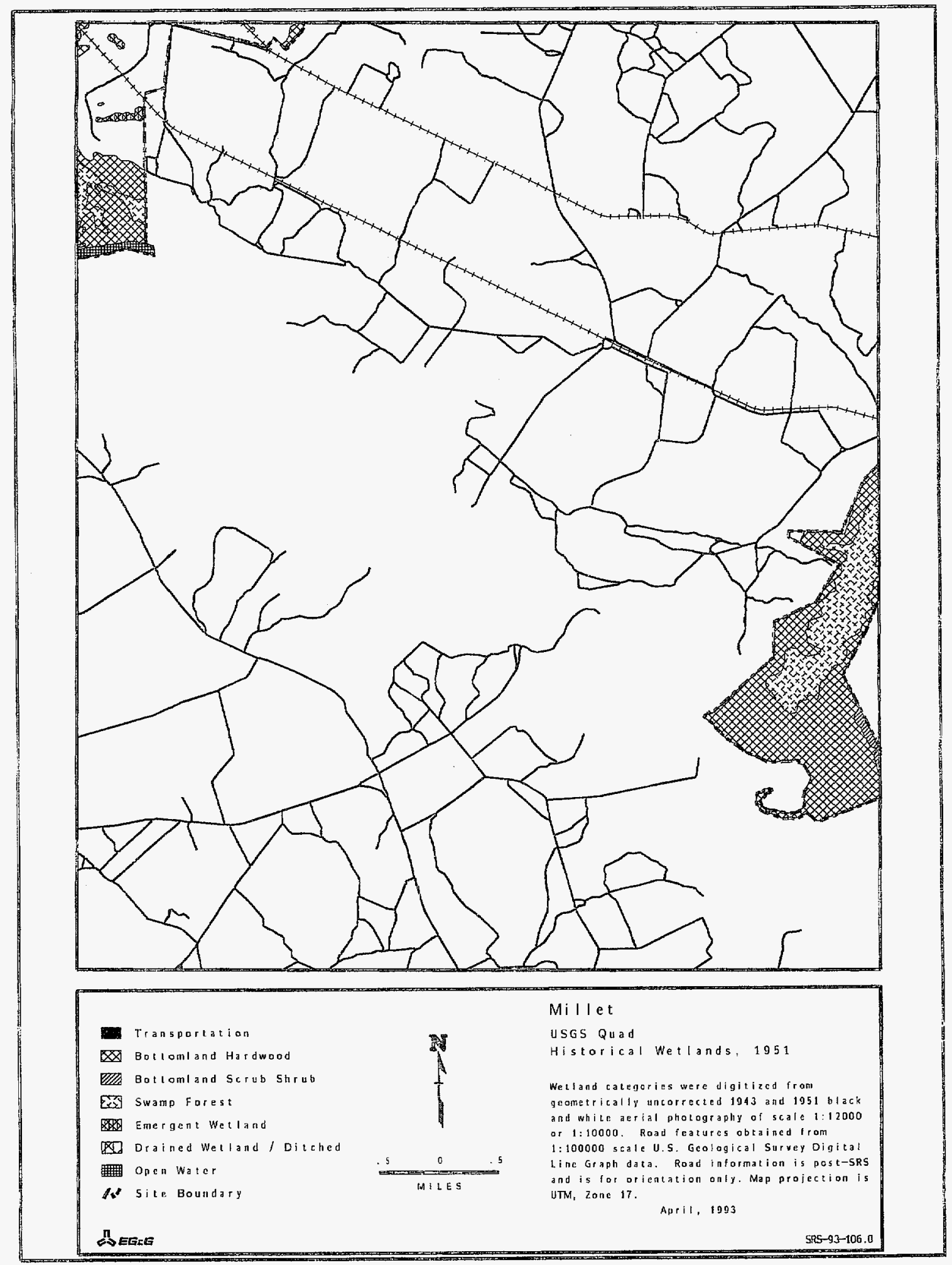




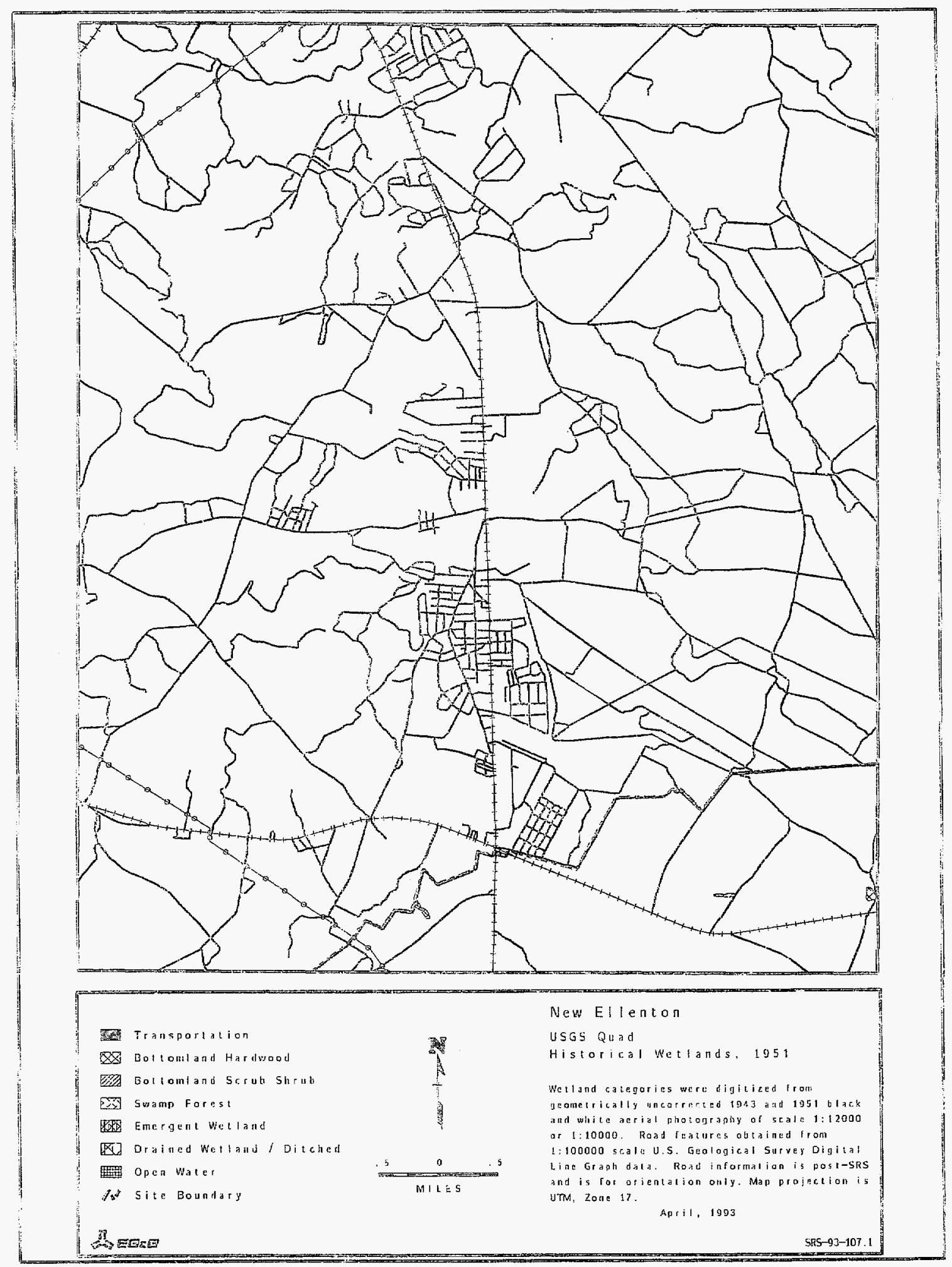




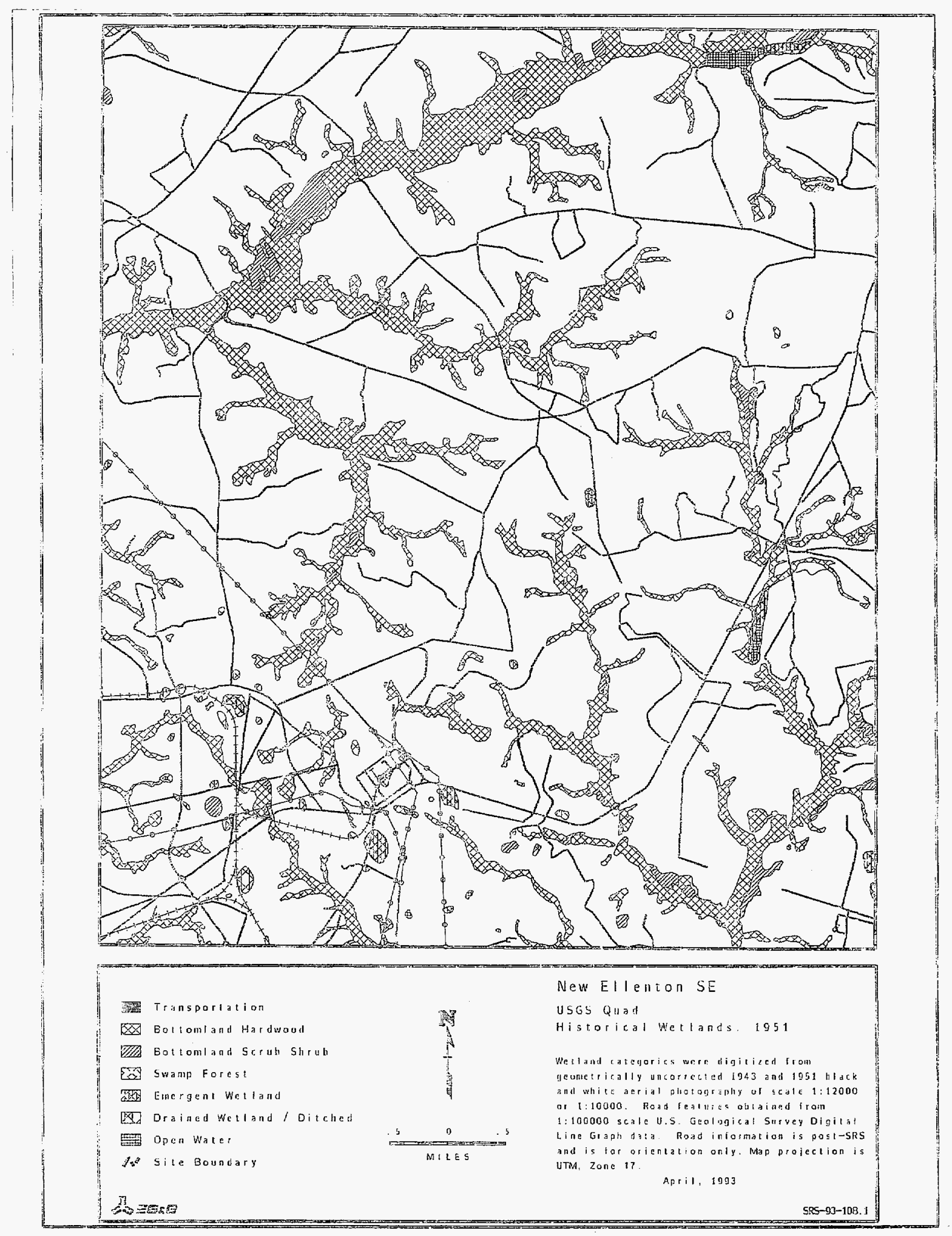




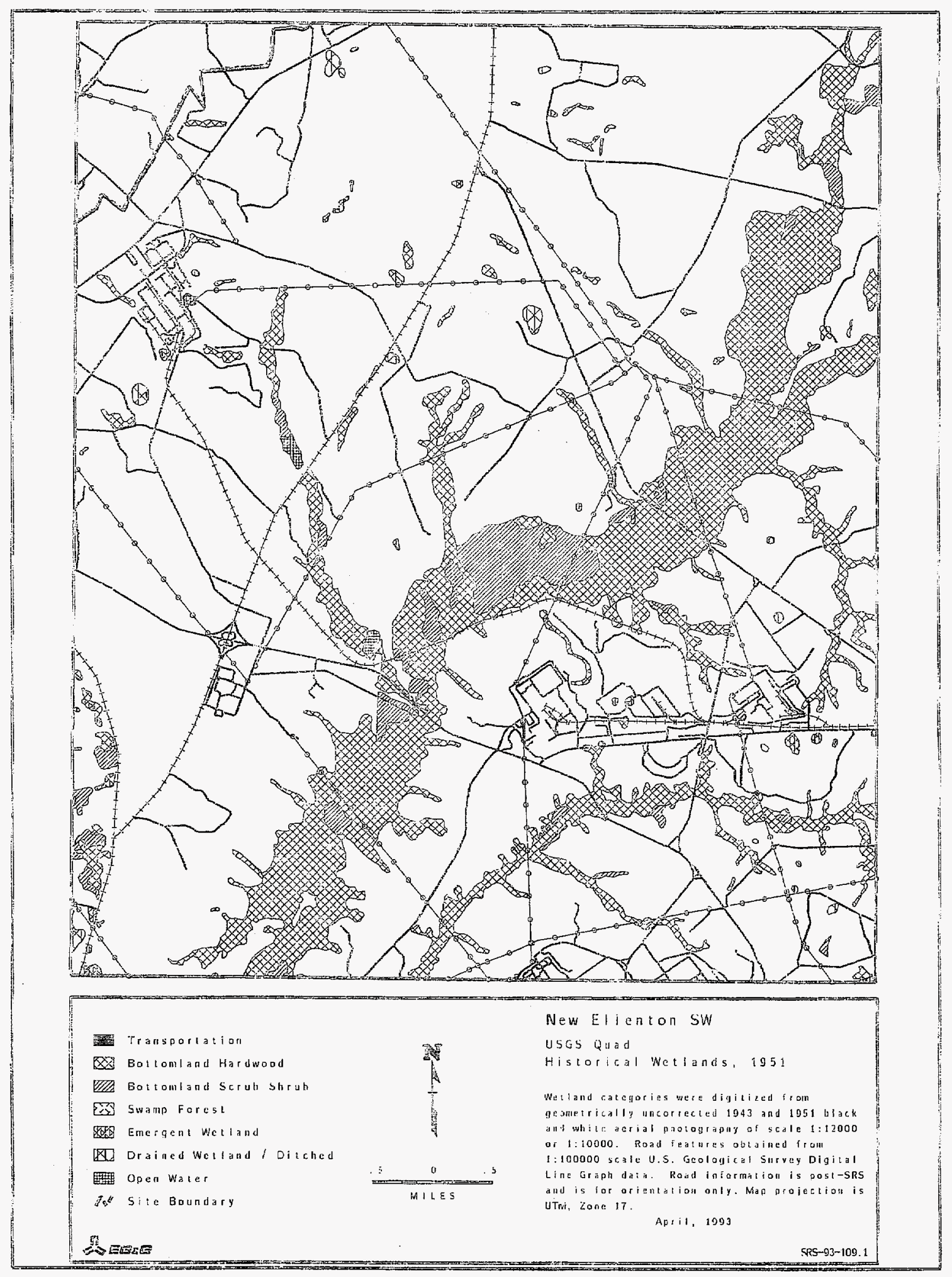




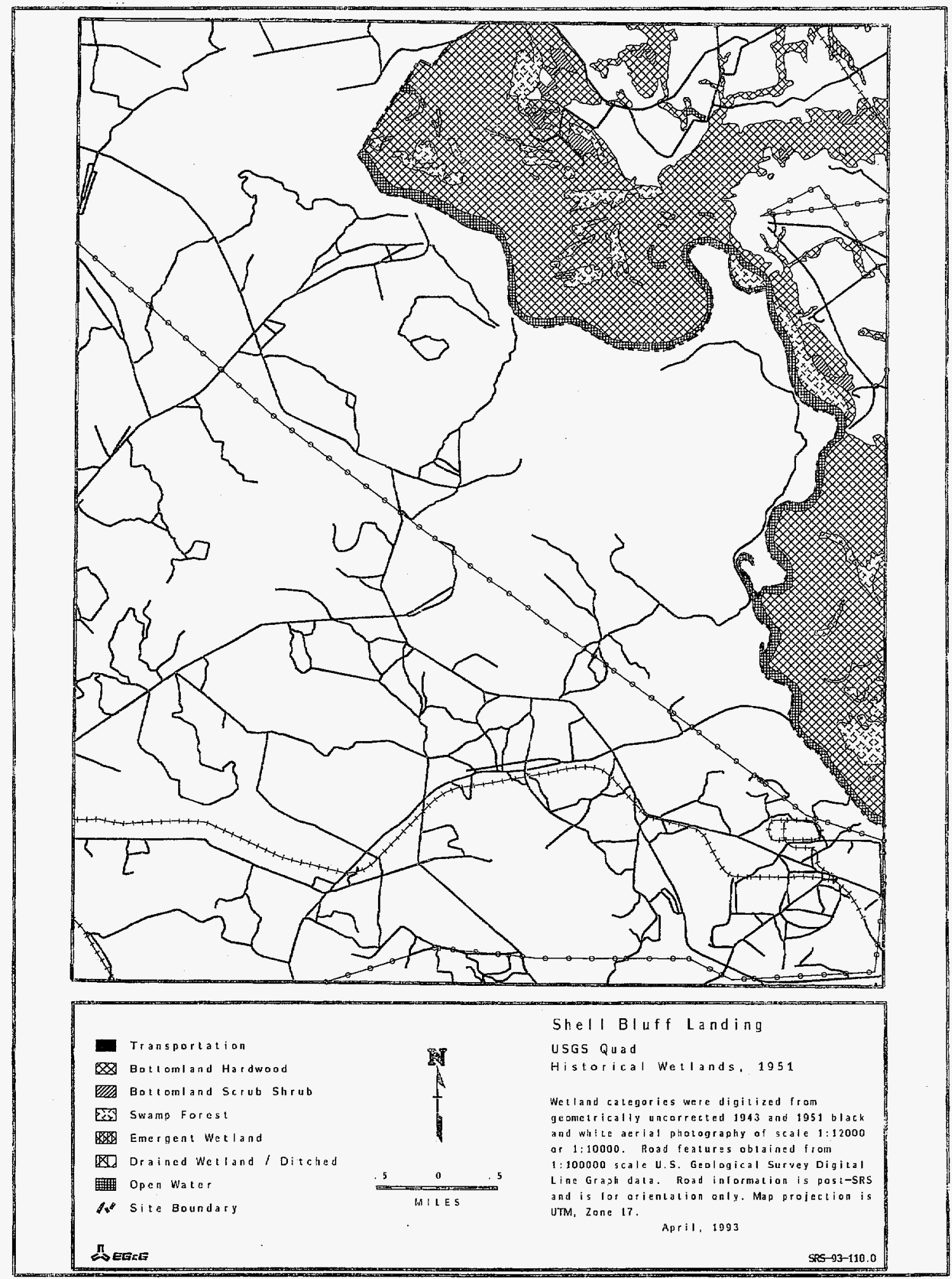




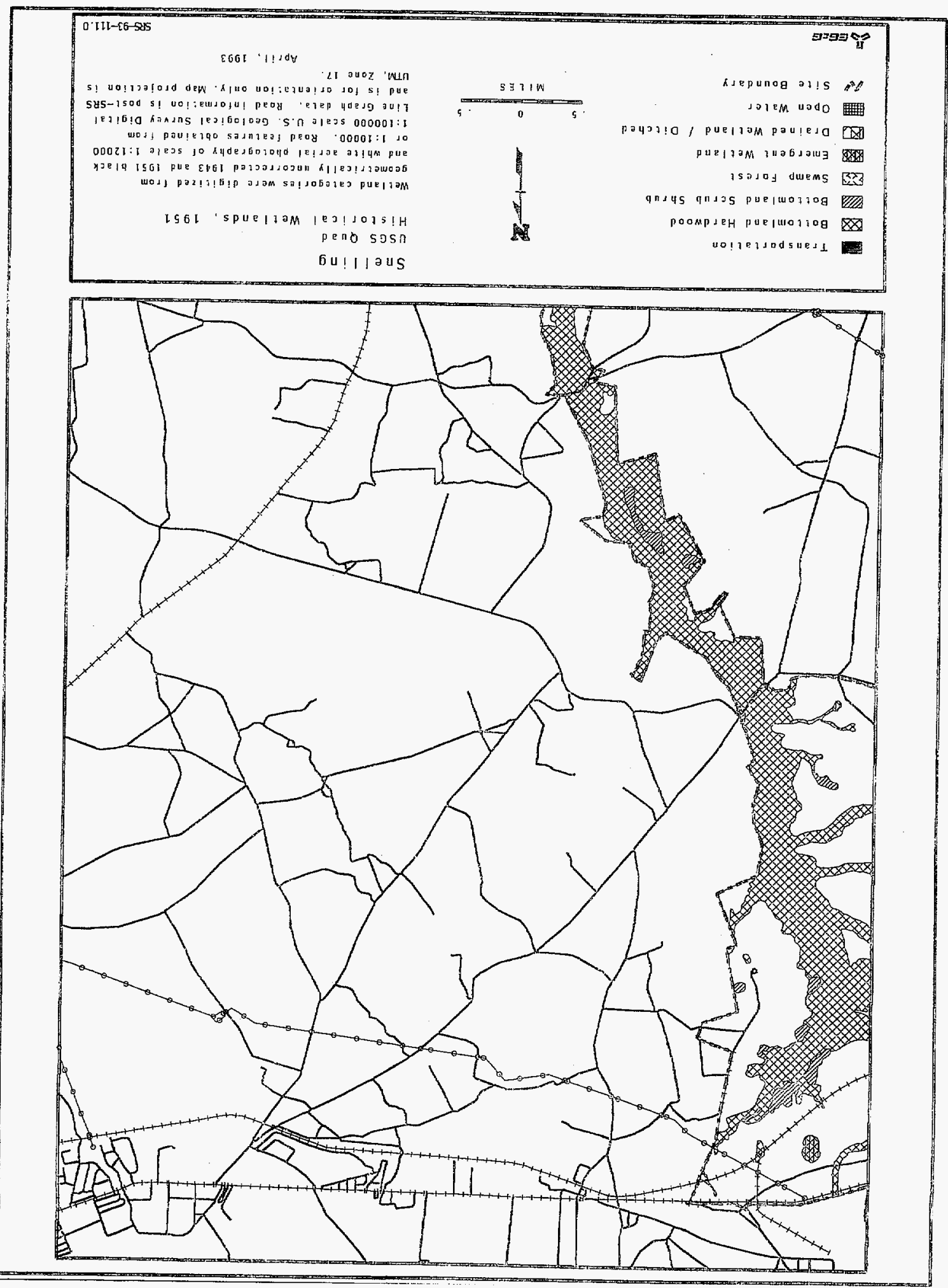




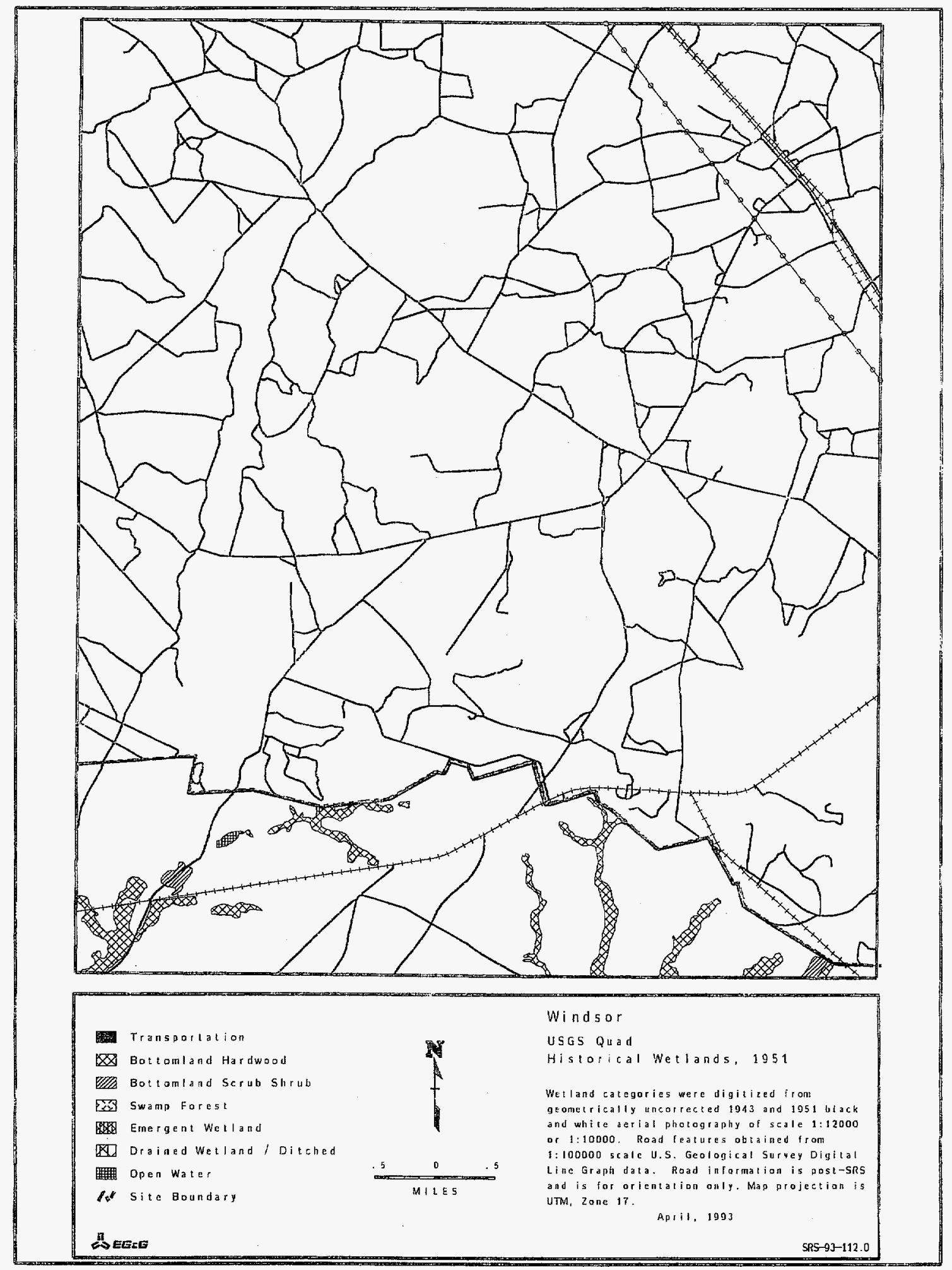




\section{REFERENCES}

Avery, T.E. Interpretation of Aerial Photographs. Burgess Publishing Company, Minneapolis, Minnesota, 1968.

Best, R.G., M.E. Wehde, and R.L. Linder. "Spectral Reflectance of Hydrophytes." Remote Sensing of Environment, Vol. 11, 1981.

Christel, L.M., and A.L. Guber. Land Cover Mapping and GIS Processing for the Savannah River Site Database, Report No. EGG 11265-1016. EG\&G/EM, Las Vegas, Nevada, 1994.

Cowardin, L.M., V. Carter, F.C. Golet, and E.T. Laroe. Classification of Wetlands and Deepwater Habitats of the United States, FWS/OBS-79-31. U.S. Fish and Wildlife Service, Office of Biological Services, Washington, D.C., 1979.

ESRI. ARC/INFO User's Guide. Environmental Systems Research Institute, Redlands, California, 1987.

Gladden, J.B., M.W. Lower, H.E. Mackey, Jr., W.L. Specht, and E.W. Wilde. Comprehensive Cooling-Water Study, Annual Report, Volume 5, Wetlands, DP-1697-5. E.I. du Pont de Nemours \& Company, Inc., Aiken, South Carolina, 1985.

Howland, W.G. "Multispectral Aerial Photography for Wetland Vegetation Mapping." Photogrammetric Engineering and Remote Sensing, January 1980, Vol. VLVI, No. 1, pp 87-99.

Paine, D.P. Aerial Photography and Image Interpretation for Resource Management. John Wiley and Sons, Inc., 1981.

Schalles J.F., R.R. Sharitz, J.W. Gibbons, G.J. Leversee, and J.N. Knox. Carolina Bays of the Savannah River Plant, SRS-NERP-18. DOE Savannah River Plant National Environmental Research Park Program, Aiken, South Carolina, 1989.

Shima, L.J., R.R. Anderson, and V.P. Carter. "The Use of Aerial Color Infrared Photography in Mapping the Vegetation of a Freshwater Marsh." Chesapeake Science, Vol. 17, No. 2, 1976.

Steffensen D.A., and F.E. McGregor. "The Application of Aerial Photography to Estuarine Ecology." Aquatic Botany, Vol. 2, 1976, pp 3-11.

Tinney, L.R., C.E. Ezra, and H.E. Mackey, Jr. Stream Corridor and Delta Wetlands Change Assessments, Savannah River Plant, Aiken, South Carolina, DOE(ONS-SRL)-8604. EG\&G/EM, Las Vegas, Nevada, 1986. 
DOE/DP

L. E. Gordon-Hagerty (1)

O.W. Taylor

(1)

(25)

OSTI

DOE/NV

M.R. Dockter

C. A. Santilli

DOE/SA

E. C. Goodson

A. B. Gould, Jr.

S. R. Wright

(1)
SRS/WSRC
A. L. Boni
J. B. Gladden
H.E. Mackey
D. B. Moore-Shedrow

(1)

(1)

(3)

(1)

\section{EG\&G/EM}

$\begin{array}{ll}\text { Z. G. Burson } & \text { LVAO } \\ \text { L.M. Christel } & \text { LVAO } \\ \text { J.F. Doyle } & \text { LVAO } \\ \text { G.R. Shipman } & \text { WAMO } \\ \text { L. R. Tinney } & \text { LVAO } \\ \text { W. J. Tipton } & \text { LVAO } \\ \text { P. H. Zavattaro } & \text { LVAO }\end{array}$

(1)

(1)

(1)

(1)

(1)

(1) W.J. Tipton LVAO (1)

P. H. Zavattaro LVAO

\section{LIBRARIES}

SIGIS

(10)

RSL

TIC

WAMO 